\title{
Inhibin, activin, follistatin and FSH serum levels and testicular production are highly modulated during the first spermatogenic wave in mice
}

\author{
Badia Barakat ${ }^{1}$, Anne E O'Connor ${ }^{1}$, Elspeth Gold ${ }^{1}$, David M de Kretser ${ }^{1,2}$ and Kate L Loveland ${ }^{1,2}$ \\ ${ }^{1}$ Monash Institute of Medical Research, Monash University, 27-31 Wright Street, Clayton, Melbourne VIC 3168, \\ Australia and ${ }^{2}$ The Australian Research Council Centre of Excellence in Biotechnology and Development, Australia \\ Correspondence should be addressed to K Loveland; Email: kate.loveland@med.monash.edu.au
}

\begin{abstract}
Testicular development is governed by the combined influence of hormones and proteins, including FSH, inhibins, activins and follistatin (FST). This study documents the expression of these proteins and their corresponding mRNAs, in testes and serum from mice aged 0 through 91 days post partum (dpp), using real-time PCR, in situ hybridisation, immunohistochemistry, ELISA and RIA. Serum immunoactive total inhibin and FSH levels were negatively correlated during development, with FSH levels rising and inhibin levels falling. Activin A production changed significantly during development, with subunit mRNA and protein levels declining rapidly after 4 dpp, while simultaneously levels of the activin antagonists, FST and inhibin/activin $\beta_{C}$, increased. Inhibin/activin $\beta_{A}$ and $\beta_{B}$ subunit mRNAs were detected in Sertoli, germ and Leydig cells throughout testis development, with the $\beta_{A}$ subunit also detected in peritubular myoid cells. The $\alpha, \beta_{A}, \beta_{B}$ and $\beta_{C}$ subunit proteins were detected in Sertoli and Leydig cells of developing and adult mouse testes. While $\beta_{A}$ and $\beta_{B}$ subunit proteins were observed in spermatogonia and spermatocytes in immature testes, $\beta_{C}$ was localised to leptotene and zygotene spermatocytes in immature and adult testes. Nuclear $\beta_{A}$ subunit protein was observed in primary spermatocytes and nuclear $\beta_{C}$ subunit in gonocytes and round spermatids. The changing spatial and temporal distributions of inhibins and activins indicate that their modulated synthesis and action are important during onset of murine spermatogenesis. This study provides a foundation for evaluation of these proteins in mice with disturbed testicular development, enabling their role in normal and perturbed spermatogenesis to be more fully understood.
\end{abstract}

Reproduction (2008) 136 345-359

\section{Introduction}

The first wave of spermatogenesis in the male mouse encompasses the proliferation and differentiation of germ cells and Sertoli cells over a period of 35 days (Fig. 1A). It is regulated by a complex interaction between circulating hormones, such as follicle-stimulating hormone $(\mathrm{FSH})$ and luteinizing hormone $(\mathrm{LH})$, and locally produced factors including activins, inhibins and androgens (Mather et al. 1997, de Kretser et al. 2001). Activin and inhibin are members of the transforming growth factor- $\beta$ (TGF- $\beta$ ) superfamily that were initially identified by their ability to regulate FSH secretion at the pituitary. FSH regulates Sertoli cell function directly and germ cell development indirectly (reviewed in de Mather et al. 1997, de Kretser et al. 2001). Activins and inhibins are disulfide-linked dimeric proteins. The activins are homoor heterodimers of the $\beta$ subunits, $\beta_{A}, \beta_{B}$ and $\beta_{C}$, encoded by Inhba, Inhbb and Inhbc respectively. The inhibins are heterodimers of an $\alpha$ subunit (encoded by Inha) and one of the same $\beta$ subunits shared with the activins. The activin/inhibin nomenclature reflects the subunit composition of the proteins, and the following have been detected in mammalian cells and/or cell lines: activin $A$ $\left(\beta_{A}-\beta_{A}\right)$, activin $B\left(\beta_{B}-\beta_{B}\right)$, activin $A B\left(\beta_{A}-\beta_{B}\right)$, activin $C$ $\left(\beta_{C}-\beta_{C}\right)$, activin $A C\left(\beta_{A}-\beta_{C}\right)$, inhibin $A\left(\alpha-\beta_{A}\right)$ and inhibin B $\left(\alpha-\beta_{\mathrm{B}}\right)$ (Yu et al. 1994, Groome et al. 1996, Vihko et al. 1998, O'Connor et al. 1999, Mellor et al. 2000, 2003, Muttukrishna et al. 2000, Vejda et al. 2002).

The $\beta_{\mathrm{A}}$ subunit protein has previously been detected by immunohistochemistry in Sertoli cells, peritubular myoid cells, Leydig cells, gonocytes and endothelial cells in the testes of rats aged 3-9 days post partum (dpp; Meehan etal. 2000) and activin A is secreted by rat Sertoli and peritubular myoid cells in vitro (de Winter et al. 1993, 1994, Buzzard et al. 2003). The addition of activin A to cultures of rat testis fragments or cells enhances the FSHmediated stimulation of immature Sertoli cell proliferation (Boitani et al. 1995, Meehan et al. 2000, Buzzard et al. 2003). Activin A increases gonocyte numbers in testis cultures from 3-day-old rats (Meehan et al. 2000) and inhibits the proliferative action of FSH on differentiating spermatogonia from $9 \mathrm{dpp}$ rat testis cultures (Boitani et al. 1995). The mitogenic actions of activin on Sertoli cells are also evident from the observations of delayed fertility in 

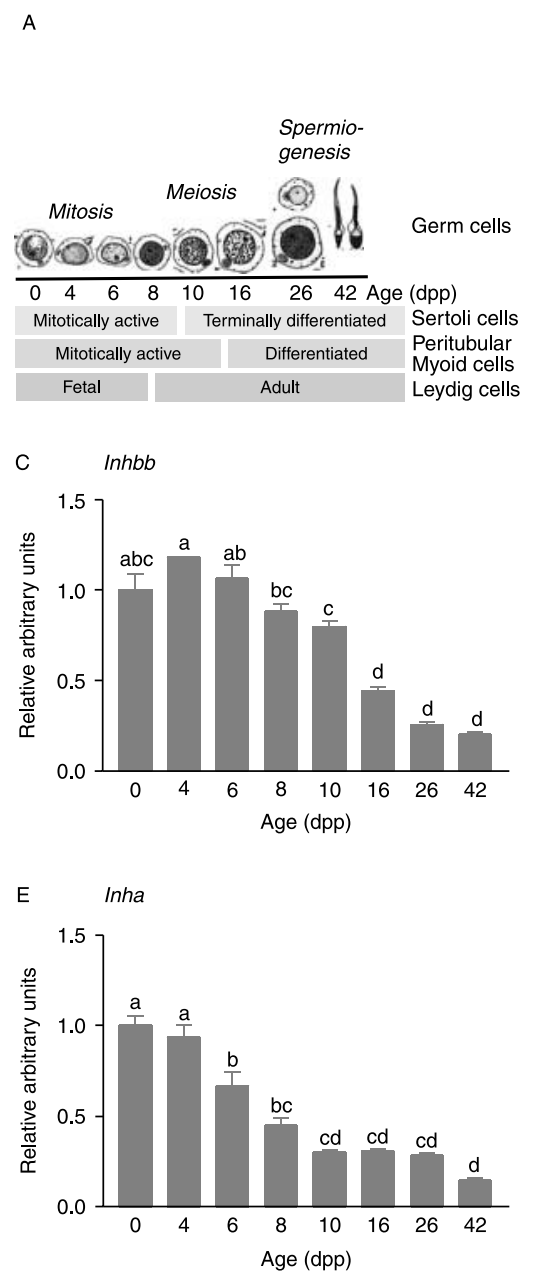
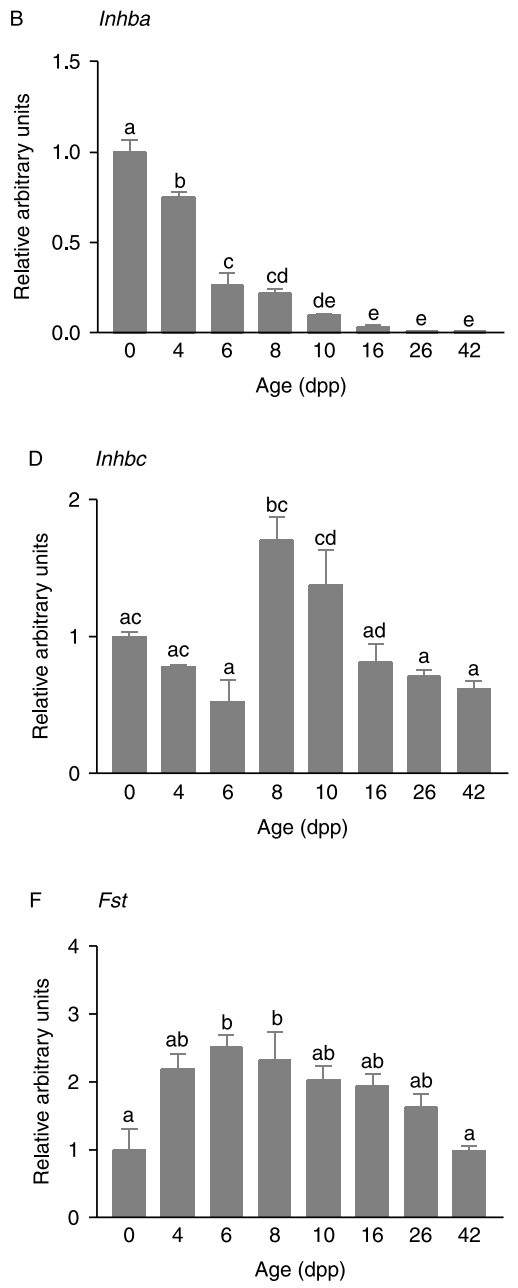

Figure 1 Development of the mouse testis and realtime PCR analysis of inhibin/activin subunits and follistatin mRNA. The first wave of murine spermatogenesis is depicted in (A). The most mature germ cells in the testis are represented at each age; gonocytes at $0 \mathrm{dpp}$, type $\mathrm{A}$ spermatogonia at $4 \mathrm{dpp}$, type B spermatogonia at $6 \mathrm{dpp}$, pre-leptotene spermatocytes at $8 \mathrm{dpp}$, zygotene spermatocytes at $10 \mathrm{dpp}$, pachytene spermatocytes at $16 \mathrm{dpp}$, round spermatids at $26 \mathrm{dpp}$ and elongating spermatids at $42 \mathrm{dpp}$. Secondary spermatocytes are also seen from age 16 dpp onward (reviewed in de Rooij \& Russell 2000; reviewed in McCarrey 1993; Orth 1993, Itman et al. 2006). Sertoli cells are mitotically active from before birth and then cease dividing and form Sertoli-Sertoli cell tight junctions between 7 and 11 $\mathrm{dpp}$, at which point they are considered terminally differentiated. Pertibular myoid cells proliferate up to 14 dpp (Vergouwen et al. 1991). Leydig cells differentiate from fetal Leydig cells to adult Leydig cells at around $7 \mathrm{dpp}$ (Vergouwen et al. 1993) and do not start to proliferate until after $21 \mathrm{dpp}$ to reach adult levels by $35 \mathrm{dpp}$ (Vergouwen et al. 1991). mRNA expression of (B) Inhba, (C) Inhbb, (D) Inhbc, (E) Inha and (F) Fst changes during testis development. Expression levels were analysed in triplicate on three different samples using real-time PCR and normalised relative to actin values. The values at each age are represented relative to the value at 0 $\mathrm{dpp}$, which was arbitrarily set to 1 . Different letters on each graph represent statistically significant data $(P<0.05)$. Data are shown as mean \pm s.E.M. male mice, smaller testis size and reduced sperm output in mice following deletion of the activin type II receptor (Matzuk etal. 1995b) or replacement of the $\beta_{A}$ subunit with the $\beta_{\mathrm{B}}$ subunit (Brown etal. 2000). Little is known about the specific role of activin $B$ in testicular function, as mice in which the $\beta_{\mathrm{B}}$ subunit gene has been deleted do not exhibit a testicular phenotype (Vassalli et al. 1994). However, in situ hybridisation studies of adult human and rat testicular tissues revealed $\beta_{\mathrm{B}}$ subunit expression in Sertoli cells, Leydig cells and germ cells from spermatogonia to round spermatids (Marchetti et al. 2003, Buzzard et al. 2004), and immunoreactive $\beta_{B}$ subunit was observed in human Leydig cells and pachytene spermatocytes and round spermatids (Marchetti et al. 2003).

The biological activity of activin is inhibited by many proteins, including follistatin (FST) and inhibin. There are two FST splice variants processed to form mature polypeptides of 288 (FST288) and 315 (FST315) amino acids. FST288 binds heparin sulphate proteoglycans and binds activins $A$ and $B$, targeting them to an endocytotic degradation pathway (Hashimoto et al. 1997), while FST315 is the circulating form (Schneyer et al. 1994).
Both isoforms bind activin with strong affinity making FST a potent antagonist of activin (Schneyer et al. 1994). Mice lacking the Fst gene die at birth (Matzuk et al. 1995c), so its precise role in post-natal testicular development has not been defined.

Mediated by their co-receptor, betaglycan, inhibins antagonise activin activity by directly binding to the activin type II receptors and thereby preventing type I receptor recruitment and activation in response to activin (Lewis etal. 2000, Wiater \& Vale 2003). When cells simultaneously synthesize $\beta$ subunits and $\alpha$ subunit, they have the potential to produce both inhibin and activin or both. Hence, the modulated production of either subunit has implications for both positive and negative effects on activin bioactivity.

Inhibin B is the major circulating inhibin in males and is produced by Sertoli and Leydig cells in the adult (de Kretser et al. 2001). The influence of inhibin B on adult spermatogenesis is not apparent, as mice that cannot produce inhibin $B$ due to deletion of the gene encoding the $\beta_{B}$ subunit are fertile (Vassalli et al. 1994, Kumar et al. 1999). However, the chronic absence of inhibin in the Inha ${ }^{-/-}$mouse (Matzuk et al. 1992) leads to development 
of stromal cell tumours by 4 weeks of age, due to the overproduction and unbalanced action of activin. Thus, inhibin is understood to play a critical role in the modulation of activin-induced Sertoli cell proliferation.

The function of the $\beta_{C}$ subunit is also ambiguous as Inhbc null mice display no overt phenotype. However, transfection studies have shown that the $\beta_{C}$ subunit forms heterodimers with the $\beta_{\mathrm{A}}$ subunit and thereby suppresses the formation of activin A homodimers, providing an additional pathway for intracellular control over activin A production and bioactivity (Mellor et al. 2003). The $\beta_{C}$ subunit mRNA is expressed in adult human and rat testes (Loveland et al. 1996, Gold et al. 2004) and $\beta_{C}$ subunit protein is detectable in the Sertoli and Leydig cells, spermatogonia, primary spermatocytes and elongating spermatids of the adult rat testis (Gold et al. 2004). However, there is currently no information about cellular sites or levels of $\beta_{C}$ mRNA or protein expression during testis development.

Several groups, including ours, have examined the levels of inhibins, activins, FSH and FST during development of the rat testis (Au et al. 1986, Sharpe et al. 1999, Buzzard et al. 2004) and in humans at various ages (Massa et al. 1992, Anawalt et al. 1996, Andersson et al. 1997). The present study offers the first comprehensive expression analysis of these proteins during mouse testis development, and it provides data that highlight changes occurring at specific developmental stages of normal testis development. While using the best currently available assays, these data are limited by the absence of specific assays for mouse inhibin A and B and by the absence of reliable activin B assays. However, this report delineates discrete changes in the cellular sites of mRNA and protein synthesis that correspond to developmentally regulated production of activin and inhibin proteins. The data illustrate that their production is linked with dynamic circulating levels of these factors and of FSH, corresponding to key stages in germ cell development and testicular maturation.

\section{Results}

\section{Levels of inhibin/activin subunits and Fst mRNAs in the mouse testis}

The total testis Inhba mRNA levels (Fig. 1B) decline rapidly in the first week of spermatogenesis, with the level down by $75 \%$ at 6 compared with $0 \mathrm{dpp}$ $(P<0.001)$. Inhba mRNA levels continue to fall to $3 \%$ of the $0 \mathrm{dpp}$ value $(P<0.001)$ at $16 \mathrm{dpp}$ and $0.4 \%$ $(P<0.001)$ at $42 \mathrm{dpp}$ (adulthood). In contrast, the Inhbb mRNA levels (Fig. 1C) remain high during the first week of spermatogenesis and decline after $10 \mathrm{dpp}(P<0.05$ between 10 and $16 \mathrm{dpp}$ ). This decline corresponds to the time when Sertoli cells become terminally differentiated and germ cells first enter meiosis. The Inhbb levels continue to decline to $25 \%$ of the 0 dpp level at 26 and $42 \mathrm{dpp}(P<0.001)$.
The Inhbc mRNA levels (Fig. 1D) display a different profile to Inhba and Inhbb, with the lowest levels measured at $6 \mathrm{dpp}$ followed by a $227 \%$ increase at $8 \mathrm{dpp}(P<0.001)$. The Inhbc mRNA levels then decline significantly at $16 \mathrm{dpp}(P<0.01$ compared with $8 \mathrm{dpp})$ and remain low through to adulthood $(P<0.01$ between 8 and 26/42 dpp). The Inha mRNA values (Fig. 1E) show a progressive decline at 6,8 and $10 \mathrm{dpp}(P<0.001$, between 6 and $10 \mathrm{dpp}$ values) when levels are 30\% of that measured at birth; they decline further to a nadir at $42 \mathrm{dpp}$, reaching an expression level that is $15 \%$ of the 0 dpp level $(P<0.001)$.

Fst mRNA levels (Fig. 1F) exhibit a profile opposite to that of Inhba, with the level $119 \%$ higher $(P=0.053)$ at $4 \mathrm{dpp}$ and $150 \%$ higher at $6 \mathrm{dpp}(P<0.01)$ compared with $0 \mathrm{dpp}$. Fst levels remain relatively high at subsequent ages to $26 \mathrm{dpp}$ and decline to levels measured at birth at $42 \mathrm{dpp}$ $(P<0.05$; comparing days $6-8$ with day 42$)$.

These data correlate well with information derived from Affymetrix microarrays in the GEO profile database (Small et al. 2005; http://www.ncbi.nlm.nih.gov/geo/).

\section{Cellular localisation of mRNAs}

Sertoli and Leydig cells contain mRNAs encoding both Inhba and Inhbb subunits from the time of birth through to adulthood (Fig. 2). Only Inhba is detected in the peritubular myoid cells throughout testicular development (Fig. 2A and B insets, C and D). At $0 \mathrm{dpp}$, the gonocytes do not contain detectable levels of either of the subunit mRNAs (Fig. 2A and I), but by $3 \mathrm{dpp}$, the spermatogonia display a signal for both subunit mRNAs, with the signal being more intense than that in Sertoli cells (Fig. 2B and J). At $15 \mathrm{dpp}$, the signal intensity observed for Inhba and Inhbb mRNAs in germ cells appears dependent on their state of maturation, with spermatogonia and pre-leptotene/ leptotene spermatocytes showing a more intense signal than pachytene spermatocytes (Fig. 2C and K). In addition, the Sertoli cell Inhbb signal intensity varies between tubule cross-sections in accordance with the stage of the seminiferous cycle, and this pattern continues throughout testicular development to adulthood. The signal intensity is the greatest in stage VII Sertoli cells than at other stages (Fig. 2L). In the adult testis, both subunits are observed with the highest intensity in spermatogonia and pre-leptotene/leptotene spermatocytes and with progressively decreasing intensity in pachytene spermatocytes, round spermatids and elongating spermatids (Fig. 2D and L).

\section{Cellular localisation of proteins}

Immunohistochemistry revealed that, as with mRNA transcripts, the activin/inhibin $\beta_{\mathrm{A}}$ and $\beta_{\mathrm{B}}$ subunit proteins are detected in the Sertoli and Leydig cells throughout testicular development (Fig. 3). The $\beta_{\mathrm{c}}$ and inhibin $\alpha$ subunit 

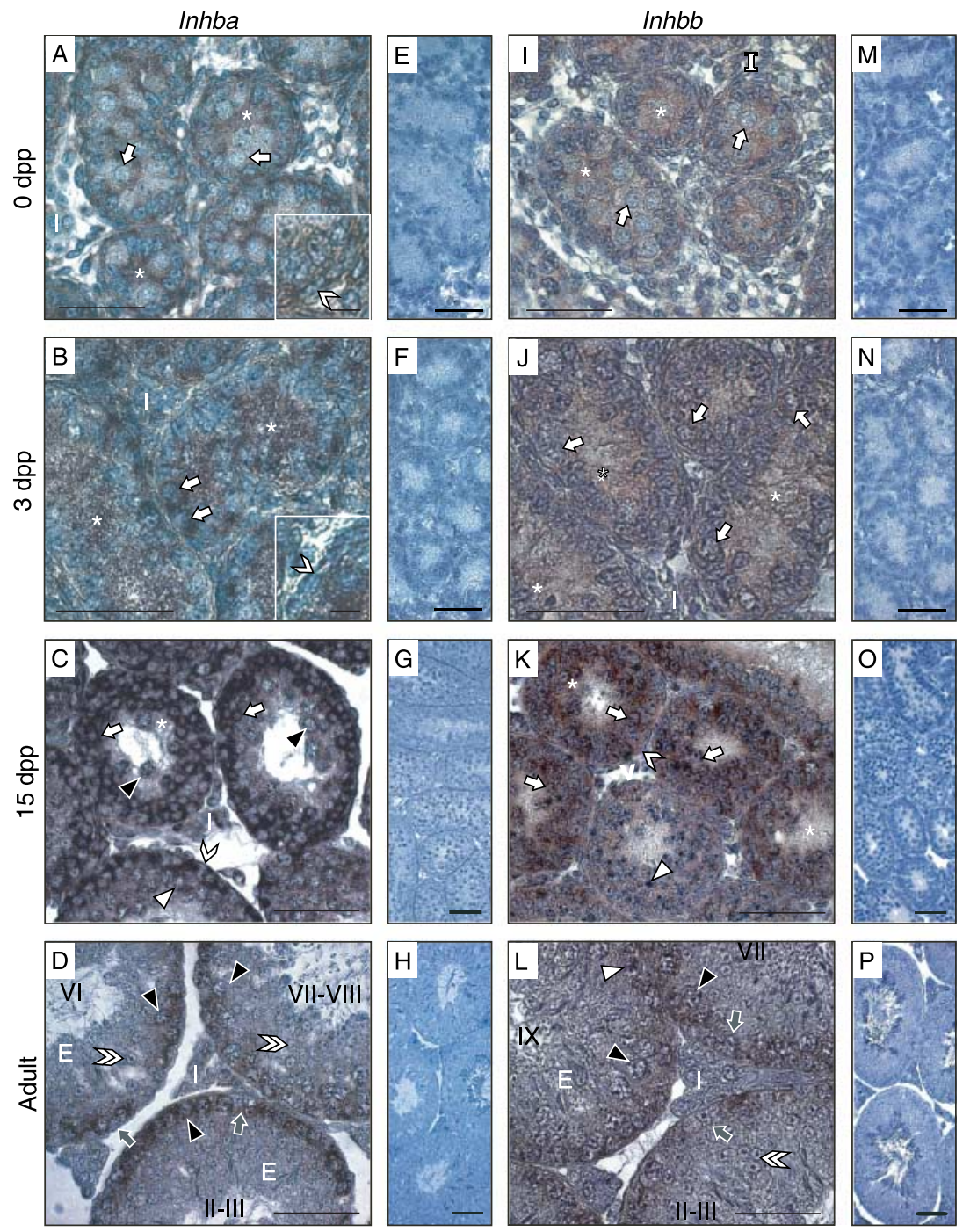

Figure 2 Cellular localisation of Inhba and Inhbb subunit mRNAs in mouse testes from birth to adulthood. Localisation using in situ hybridisation of the (A-D) Inhba and (I-L) Inhbb subunit mRNAs is shown at (A and $\mathrm{I}) 0 \mathrm{dpp}$, ( $\mathrm{B}$ and $\mathrm{J}) 3 \mathrm{dpp}$, ( $\mathrm{C}$ and K) $15 \mathrm{dpp}$ and ( $\mathrm{D}$ and $\mathrm{L}$ ) adult ages. Both subunits are observed in the Sertoli cells, Leydig cells and spermatogonia at all ages, spermatocytes at 15 $\mathrm{dpp}$, and spermatocytes and round spermatids at adult. No signal is observed with corresponding sense probes at all ages (negative controls for (E-H) Inhba and (M-P) Inhbb). The stages of the seminiferous epithelium are marked in the adult tubule cross-sections. All sections were counterstained with Harris haematoxylin. The asterisk symbol indicates the Sertoli cell cytoplasm (A-C and $\mathrm{I}-\mathrm{K})$; dark arrow points to Sertoli cell nucleus $(\mathrm{D}$ and $\mathrm{L})$; white arrow points to gonocytes (A and $\mathrm{I})$, spermatogonia (B and J) and pre-leptotene/leptotene spermatocytes ( $\mathrm{C}$ and $\mathrm{K})$; white arrowhead points to zygotene spermatocytes $(\mathrm{C}-\mathrm{D}$ and $\mathrm{K}-\mathrm{L}$ ); dark arrowhead points to pachytene spermatocytes (C-D and $\mathrm{K}-\mathrm{L})$; double arrow points to round spermatids ( $\mathrm{D}$ and $\mathrm{L}$ ); $\mathrm{E}$ indicates elongating spermatids ( $\mathrm{D}$ and $\mathrm{L}$ ); $\mathrm{v}$-shaped arrowhead points to pertibular myoid cells; I indicates intertubular areas where Leydig cells are found. Scale bar represents $100 \mu \mathrm{m}$ for $A-D$ and $I-L, 10 \mu \mathrm{m}$ for $A$ and $C$ insets and $50 \mu \mathrm{m}$ for negative control sections $\mathrm{E}-\mathrm{H}$ and $\mathrm{M}-\mathrm{P}$. proteins are also present in these cells, with the $\beta_{\mathrm{A}}$ and $\beta_{\mathrm{c}}$ subunit proteins also observed in peritubular myoid cells (Fig. 4). However, protein cellular expression in some germ cells differs to that observed for mRNAs. At $0 \mathrm{dpp}$, some gonocytes showed cytoplasmic localisation of the $\beta_{\mathrm{A}}$ subunit protein and at $15 \mathrm{dpp}$ this subunit is detected in spermatogonia; however, this signal does not persist in spermatogonia of the adult (Fig. $3 \mathrm{~A}-\mathrm{C}$ ). The $\beta_{\mathrm{A}}$ subunit protein is evident in the nucleus of leptotene and zygotene spermatocytes at $15 \mathrm{dpp}$ (Fig. 3B, insets) and in zygotene and early pachytene spermatocytes at stages $X-$ III of the adult testis, but this signal is less obvious in the pachytene and diplotene spermatocytes of stages IV-XI (Fig. 3C, insets).

The $\beta_{\mathrm{B}}$ subunit protein is detected in gonocytes at $0 \mathrm{dpp}$ (Fig. 3D), and in spermatogonia and primary spermatocytes at $15 \mathrm{dpp}$ (Fig. 3E), but not in the spermatogonia and spermatocyte populations of the adult testis (Fig. 3F). However, the $\beta_{\mathrm{B}}$ subunit protein is detected in elongating spermatids in adults (Fig. 3F). The negative controls relating to each protein detected are shown (Fig. 3G-I).
The inhibin $\alpha$ subunit protein was primarily detected in the Sertoli cells throughout post-natal testicular development. At 0 and $3 \mathrm{dpp}$, adjacent Sertoli cells differed in the inhibin $\alpha$ protein signal intensity (Fig. 4A), and at $15 \mathrm{dpp}$ this differing signal intensity was also observed between tubule cross-sections (Fig. 4B). In the adult testis (Fig. 4C), the Sertoli cell inhibin $\alpha$ signal was stage-specific with highest intensity at stages X-III of the seminiferous epithelium cycle. The negative controls for each age are shown in Fig. 4D-F.

Immunolocalisation of the activin/inhibin $\beta_{C}$ subunit protein was similar to that of the $\beta_{\mathrm{A}}$ subunit protein, with protein visualised in the cytoplasm of Leydig, Sertoli and peritubular myoid cells throughout testicular development (Fig. 4G-I). In germ cells at $0 \mathrm{dpp}$, the $\beta_{\mathrm{C}}$ subunit protein was localised to the nuclei of gonocytes (Fig. 4G) and, from $15 \mathrm{dpp}$ to adulthood, it was detected only in the cytoplasm of pre-leptotene/leptotene and zygotene spermatocytes and in the nucleus of round spermatids (Fig. $4 \mathrm{H}$ and I) but was absent from elongating spermatids and spermatogonia 

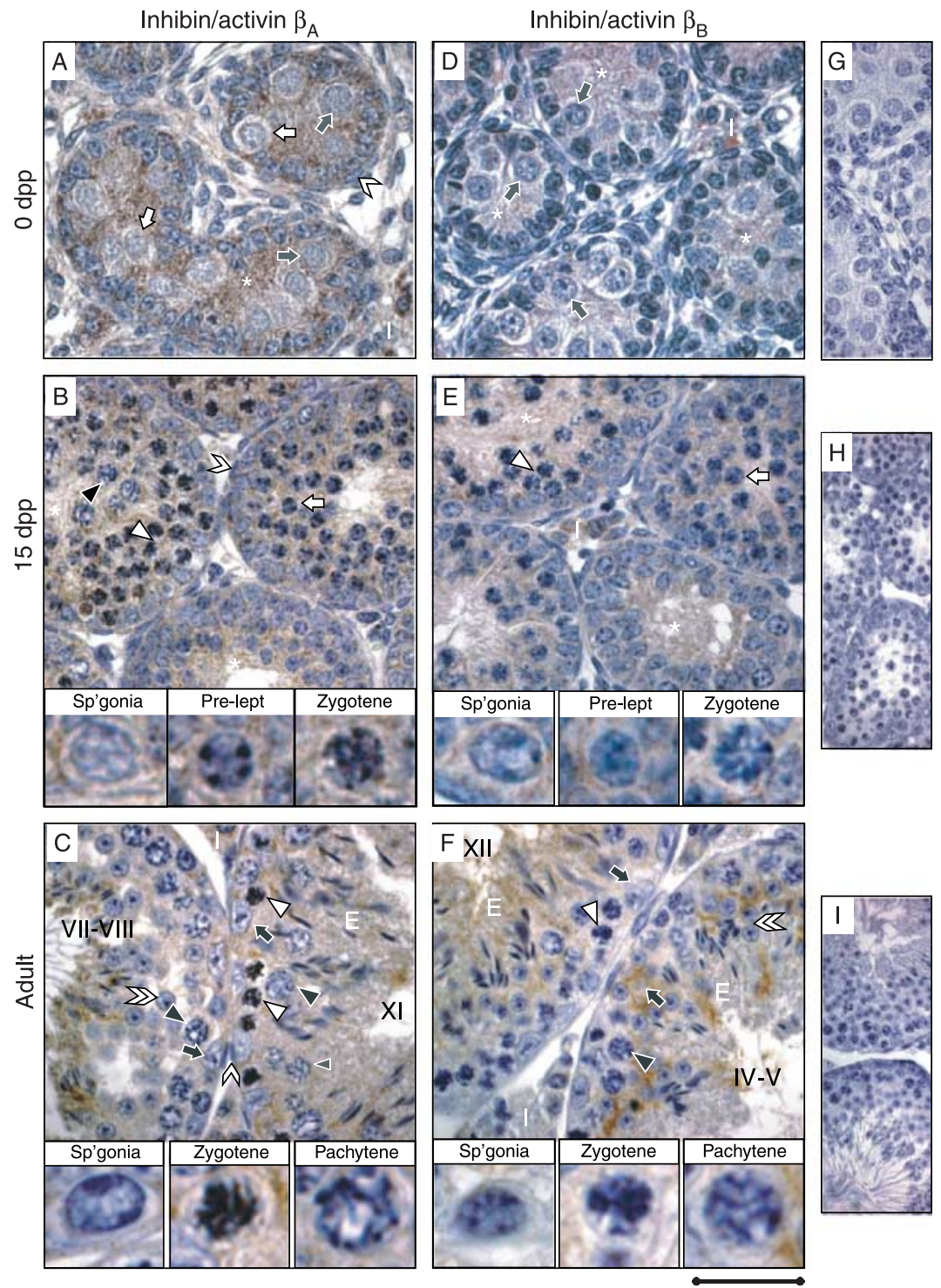

Figure 3 Immunolocalisation of inhibin/activin $\beta_{A}$ and $\beta_{\mathrm{B}}$ subunits in mouse testes from birth to adulthood. Photomicrographs of mouse testes at ages (A and D) 0 dpp, (B and E) $15 \mathrm{dpp}$ and $(C$ and $F)$ adult, immunostained for the inhibin/activin $\beta_{\mathrm{A}}(\mathrm{A}-\mathrm{C})$ and $\beta_{\mathrm{B}}(\mathrm{D}-\mathrm{F})$ subunits. Magnified images of a spermatogonia (Sp'gonia), pre-leptotene spermatocyte (Pre-lept) and zygotene spermatocyte from $15 \mathrm{dpp}$ testes of are shown ( $B$ and $E$ insets). Magnified images of a spermatogonia, zygotene spermatocyte and pachytene spermatocyte from adult testes are shown ( $\mathrm{C}$ and $\mathrm{F}$ insets). The stages of the seminiferous epithelium are marked in the adult tubule cross-sections in $\mathrm{C}$ and $\mathrm{F}$. G-I show the negative controls for each age relating to both proteins detected. All sections are counterstained with Harris haematoxylin. Asterisk symbol shows Sertoli cell cytoplasm (A, B, D and E); dark arrow points to Sertoli cell nucleus (C and F); white arrow points to gonocytes with negative signal and dark arrow points to gonocytes with positive signal (A and D); white arrow points to preleptotene/leptotene spermatocytes (B, C, E and F); white arrowhead points to zygotene spermatocytes (B, C, E and F); dark arrowhead points to pachytene spermatocytes (B, C, E and F); double arrow points to round spermatids ( $\mathrm{C}$ and $\mathrm{F}$ ); $\mathrm{E}$ indicates elongating spermatids ( $\mathrm{C}$ and $\mathrm{F}$ ); $\mathrm{V}$-shaped arrowhead points to pertibular myoid cells; I indicates interstitial areas containing Leydig cells. Scale bar represents $50 \mu \mathrm{m}$ for A-F, $80 \mu \mathrm{m}$ for $\mathrm{G}-\mathrm{I}$ and $12.5 \mu \mathrm{m}$ for magnified images of individual cells.
(Fig. 4I). The negative controls for each age are shown in Fig. 4J-L. A summary of these cellular localisation data is provided in Table 1.

\section{Testis weights}

Testis weights increased progressively from $3.32 \pm 0.26$ $\mathrm{mg}$ (paired weight) at birth to $189.8 \pm 4.2 \mathrm{mg}$ (paired weight) at $91 \mathrm{dpp}$ (Fig. 5A).

\section{Testicular levels of activin, inhibin and FST}

The concentrations of activin A, inhibin and FST per nanogram of testicular homogenate (Fig. 5B-D) provide a measure of their local concentrations, whereas the total testicular content takes into account the mass of the growing testis and provides an indication of the amount available for release into the circulation.
The testicular immunoactive inhibin concentrations rose significantly from 0 to $2 \mathrm{dpp}(P<0.05)$ and peaked at $4 \mathrm{dpp}(995.6 \pm 27.3 \mathrm{ng} / \mathrm{g}$ testis; Fig. 5B), corresponding to the period when gonocytes resume mitosis, migrate to the basement membrane and transform into spermatogonia. Thereafter, inhibin concentrations progressively declined to be significantly lower at 25 dpp $(P<0.05$ compared with $16 \mathrm{dpp})$ and plateau beyond day $45 \mathrm{dpp}(248.2 \pm 15.52 \mathrm{ng} / \mathrm{g}$ testis $)$. In contrast, total testis inhibin levels rose significantly from $1.07 \pm 0.09 \mathrm{ng} /$ testis at $0 \mathrm{dpp}$ to $25.5 \pm 2.1 \mathrm{ng} /$ testis at $25 \mathrm{dpp}(P<0.001)$ and remained stable thereafter.

The testicular concentrations of activin A (Fig. 5C) significantly declined from 0 to $1 \mathrm{dpp}(P<0.01)$ before rising to a peak at $3 \mathrm{dpp}(13.6 \pm 0.5 \mathrm{ng} / \mathrm{g}$ testis, $P<0.001$ compared with 1 and $2 \mathrm{dpp}$ ). Subsequently, the testis concentrations again declined by $8 \mathrm{dpp}(3.4 \pm 0.4 \mathrm{ng} / \mathrm{g}$ testis, $P<0.001$ compared with each previous age) and 

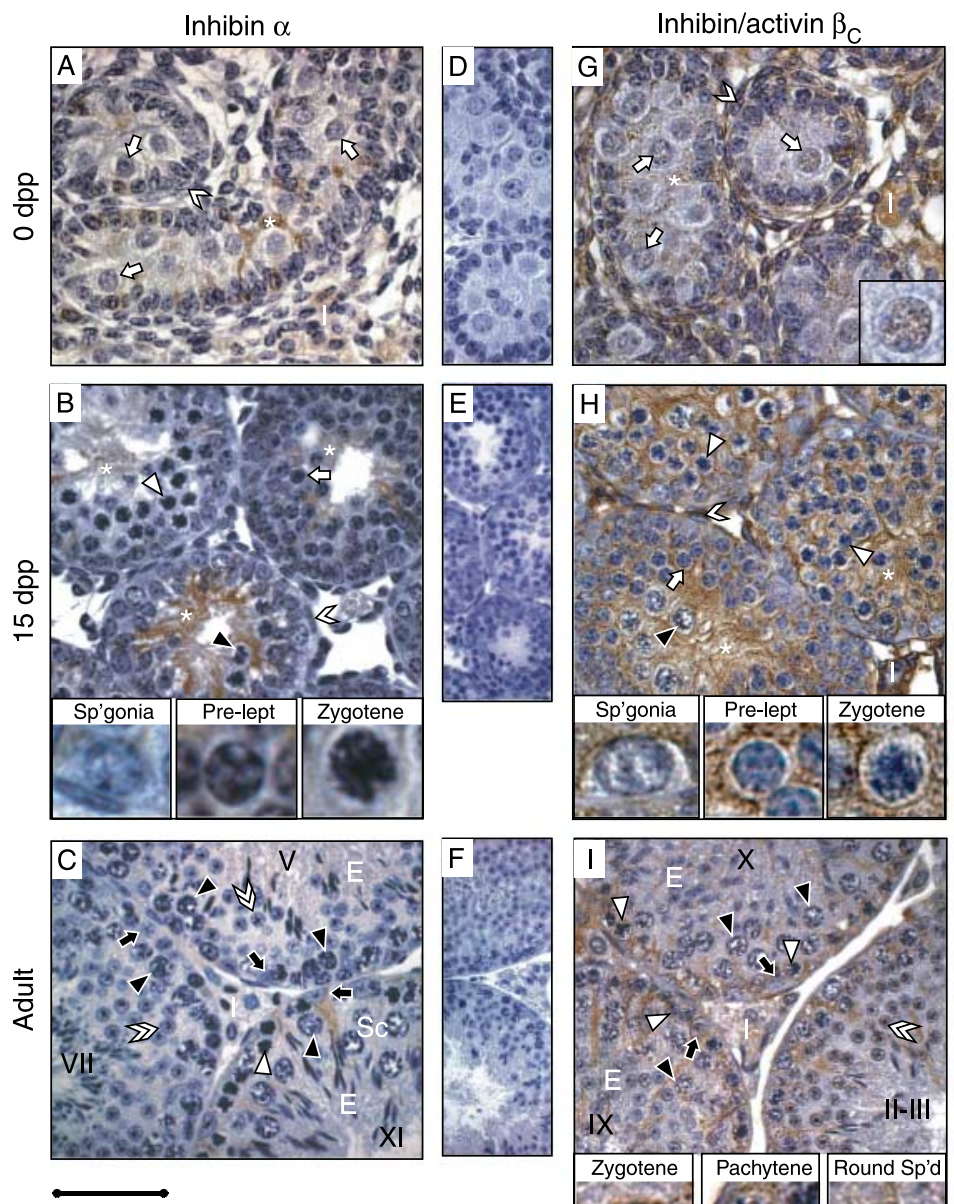

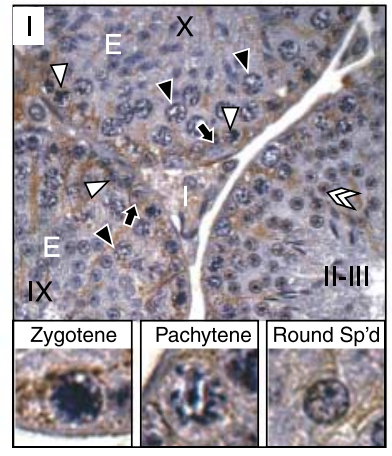

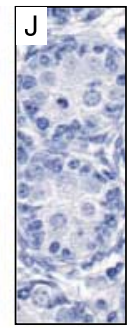
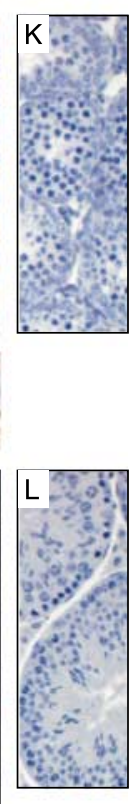

Figure 4 Immunolocalisation of inhibin $\alpha$ and inhibin/activin $\beta_{C}$ subunits in mouse testes from birth to adulthood. Photomicrographs of mouse testes at ages ( $\mathrm{A}$ and $\mathrm{G}) 0 \mathrm{dpp},(\mathrm{B}$ and $\mathrm{H}) 15 \mathrm{dpp}$ and $(\mathrm{C}$ and $\mathrm{I})$ adult, immunostained for the $(\mathrm{A}-\mathrm{C})$ inhibin $\alpha$ and $(\mathrm{G}-\mathrm{l})$ inhibin/activin $\beta_{\mathrm{C}}$ subunits. Magnified images of a spermatogonia (Sp'gonia), pre-leptotene spermatocyte (Pre-lept) and zygotene spermatocyte from $15 \mathrm{dpp}$ testes of $\mathrm{B}$ and $\mathrm{H}$ are shown (insets). Magnified images of a zygotene spermatocyte, pachytene spermatocyte and round spermatid from adult testes of I are shown (insets). The stages of the seminiferous epithelium are marked in the tubule cross-sections in C and I. D-F and $\mathrm{J}-\mathrm{L}$ show the negative controls relating to inhibin $\alpha$ and inhibin/activin $\beta_{\mathrm{C}}$ subunits respectively. All sections are counterstained with Harris haematoxylin. Asterisk symbol shows Sertoli cell cytoplasm (A, B, G and $\mathrm{H}$ ); dark arrow points to Sertoli cell nucleus ( $C$ and $I) ;$ white arrow points to gonocytes $(\mathrm{A}$ and $\mathrm{G})$; white arrow points to preleptotene/leptotene spermatocytes (B, C, H and I); white arrowhead points to zygotene spermatocytes (B, C, H and I); dark arrowhead points to pachytene spermatocytes (B, C, H and I); double arrow points to round spermatids ( $\mathrm{C}$ and $\mathrm{I}) ; \mathrm{E}$ indicates elongating spermatids (C and I); v-shaped arrowhead points to pertibular myoid cells; I indicates interstitial cell population where Leydig cells are found. Scale bar represents $50 \mu \mathrm{m}$ for $\mathrm{A}-\mathrm{C}$ and $\mathrm{G}-\mathrm{I}, 50 \mu \mathrm{m}$ for $\mathrm{D}$ and $\mathrm{J}, 80 \mu \mathrm{m}$ for $\mathrm{E}-\mathrm{F}$ and $\mathrm{K}-\mathrm{L}$ and $12.5 \mu \mathrm{m}$ for magnified images of individual cells. remained unchanged through $91 \mathrm{dpp}$. The testicular content of activin A showed parallel changes until 25 dpp but thereafter showed a significant $(P<0.001)$ increase to $0.03 \pm 0.002 \mathrm{~g} /$ testis at $91 \mathrm{dpp}$.

Testicular FST concentrations (Fig. 5D) were significantly elevated at $3 \mathrm{dpp}$ compared with $1 \mathrm{dpp}$ $(P<0.01)$, coinciding with the peak in activin levels, and continued to rise, peaking at $8 \mathrm{dpp}(90.4 \pm 8.6 \mathrm{ng} / \mathrm{g}$ testis, $P<0.001$ compared with $10 \mathrm{dpp}$ ). Thereafter, the levels decreased $(P<0.001)$ to a nadir at $25 \mathrm{dpp}$ $(28.2 \pm 0.6 \mathrm{ng} / \mathrm{g}$ testis) and remained unchanged until $91 \mathrm{dpp}$. The total testicular content of FST levels showed a different profile, increasing continuously with increasing age to peak at $91 \mathrm{dpp}(3.0 \pm 0.1 \mathrm{ng} /$ testis $)$.

\section{Serum hormone concentrations}

Serum activin A levels were the highest during the first 8 days of age (averaging $0.55 \pm 0.02 \mathrm{ng} / \mathrm{ml}$ ) and decreased significantly $(P<0.001)$ at $10 \mathrm{dpp}$ continuing to decline in successive ages to reach a nadir at $45 \mathrm{dpp}$ $(0.05 \pm 0.002 \mathrm{ng} / \mathrm{ml}, P<0.001)$ (Fig. 6). Serum FST levels steadily increased from birth, peaking at $8 \mathrm{dpp}$ $(9.2 \pm 0.4 \mathrm{ng} / \mathrm{ml}, P<0.05$ compared with $0 \mathrm{dpp})$ and remained at similar levels to $91 \mathrm{dpp}$.

Serum total inhibin levels showed a significant peak between 2 and $3 \mathrm{dpp}$ (maximum of $5.5 \pm 0.1 \mathrm{ng} / \mathrm{ml}$, $P<0.01)$, with progressively lower values measured at $10 \mathrm{dpp}(P<0.05)$ and at 45 and $91 \mathrm{dpp}$ (minimum $1.0 \pm 0.2 \mathrm{ng} / \mathrm{ml}, P<0.001)$.

FSH and inhibin levels were negatively correlated throughout development $(r=-0.72, P<0.01)$. During the first 10 days of neonatal life, FSH levels were at their lowest values, significantly declining between 2 and $4 \mathrm{dpp}$ $(P<0.01)$ and remaining low to $10 \mathrm{dpp}(1.6 \pm 0.2 \mathrm{ng} / \mathrm{ml})$. Subsequently, while inhibin levels declined, FSH levels rose between 10 and $16 \mathrm{dpp}(P<0.001)$ with an additional significant increase measured at $25 \mathrm{dpp}(11.0 \pm 0.5 \mathrm{ng} / \mathrm{ml}$, $P<0.05)$ and remaining elevated thereafter.

\section{Discussion}

This study provides the first assessment of the expression of the activins and inhibins, their binding protein, FST and $\mathrm{FSH}$ during testicular development in the normal 
Table 1 Summary of the intensity of in situ hybridisation signal for RNAs encoding Inhba and Inhbb genes and of immunohistochemsitry signal for INHA, INHBA, INHBB and INHBC proteins.

\begin{tabular}{|c|c|c|c|c|c|c|c|c|}
\hline & \multicolumn{4}{|c|}{ mRNA } & \multicolumn{4}{|c|}{ Protein } \\
\hline & $0 \mathrm{dpp}$ & $3 \mathrm{dpp}$ & $15 \mathrm{dpp}$ & Adult & $0 \mathrm{dpp}$ & $3 \mathrm{dpp}$ & $15 \mathrm{dpp}$ & Adult \\
\hline Gonocytes & $\begin{array}{l}\text { Inhba- } \\
\text { Inhbb- }\end{array}$ & & & & $\begin{array}{l}\text { INHA- } \\
\text { INHBA+ } \\
\text { INHBB+ } \\
\text { INHBC }+^{\text {N }}\end{array}$ & & & \\
\hline Mitotic spermatogonia & & $\begin{array}{l}\text { Inhba+ } \\
\text { Inhbb+ }\end{array}$ & $\begin{array}{l}\text { Inhba+ } \\
\text { Inhbb+ }\end{array}$ & $\begin{array}{l}\text { Inhba++ } \\
\text { Inhbb++ }\end{array}$ & & $\begin{array}{l}\text { INHA- } \\
\text { INHBA+ } \\
\text { INHBB+ } \\
\text { INHBC+ }\end{array}$ & $\begin{array}{l}\text { INHA- } \\
\text { INHBA+ } \\
\text { INHBB+ } \\
\text { INHBC- }\end{array}$ & $\begin{array}{l}\text { INHA- } \\
\text { INHBA- } \\
\text { INHBB- } \\
\text { INHBC- }\end{array}$ \\
\hline $\begin{array}{l}\text { Meiotic pre-leptotene, } \\
\text { leptotene \& zygotene } \\
\text { spermatocytes }\end{array}$ & & & $\begin{array}{l}\text { Inhba+ + } \\
\text { Inhbb }++\end{array}$ & $\begin{array}{l}\text { Inhba+ + } \\
\text { Inhbb++ }\end{array}$ & & & 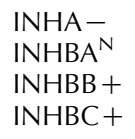 & $\begin{array}{l}\text { INHA- }^{\text {INHAN }} \\
\text { INHBA }^{\text {N }} \\
\text { INHBB- } \\
\text { INHBC+ }\end{array}$ \\
\hline $\begin{array}{l}\text { Meiotic pachytene } \\
\text { spermatocytes }\end{array}$ & & & $\begin{array}{l}\text { Inhba+ } \\
\text { Inhbb+ }\end{array}$ & $\begin{array}{l}\text { Inhba+ } \\
\text { Inhbb+ }\end{array}$ & & & $\begin{array}{l}\text { INHA- } \\
\text { INHBA+ } \\
\text { INHBB+ } \\
\text { INHBC- }\end{array}$ & $\begin{array}{l}\text { INHA- } \\
\text { INHBA } \pm \\
\text { INHBB- } \\
\text { INHBC- }\end{array}$ \\
\hline Round spermatids & & & & $\begin{array}{l}\text { Inhba+ } \\
\text { Inhbb+ }\end{array}$ & & & & $\begin{array}{l}\text { INHA- } \\
\text { INHBA- } \\
\text { INHBB- } \\
\text { INHBC+ }^{\text {N }}\end{array}$ \\
\hline Elongating spermatids & & & & $\begin{array}{l}\text { Inhba- } \\
\text { Inhbb- }\end{array}$ & & & & $\begin{array}{l}\text { INHA- } \\
\text { INHBA } \\
\text { INHBB+ } \\
\text { INHBC- }\end{array}$ \\
\hline Sertoli cells & $\begin{array}{l}\text { Inhba+ } \\
\text { Inhbb+ }\end{array}$ & $\begin{array}{l}\text { Inhba+ } \\
\text { Inhbb+ }\end{array}$ & $\begin{array}{l}\text { Inhba+ } \\
\text { Inhbb+ }\end{array}$ & $\begin{array}{l}\text { Inhba+ } \\
\text { Inhbb+ }\end{array}$ & $\begin{array}{l}\text { INHA+ }{ }^{*} \\
\text { INHBA+ } \\
\text { INHBB+ } \\
\text { INHBC+ }\end{array}$ & $\begin{array}{l}\text { INHA+ } \\
\text { INHBA+ } \\
\text { INHBB+ } \\
\text { INHBC+ }\end{array}$ & $\begin{array}{l}\text { INHA+* } \\
\text { INHBA+ } \\
\text { INHBB+ } \\
\text { INHBC+ }\end{array}$ & $\begin{array}{l}\text { INHA+* } \\
\text { INHBA+ } \\
\text { INHBB }^{*} \\
\text { INHBC }^{\text {N }}\end{array}$ \\
\hline Leydig cells & $\begin{array}{l}\text { Inhba+ } \\
\text { Inhbb+ }\end{array}$ & $\begin{array}{l}\text { Inhba+ } \\
\text { Inhbb+ }\end{array}$ & $\begin{array}{l}\text { Inhba+ } \\
\text { Inhbb+ }\end{array}$ & $\begin{array}{l}\text { Inhba+ } \\
\text { Inhbb+ }\end{array}$ & $\begin{array}{l}\text { INHA+ } \\
\text { INHBA+ } \\
\text { INHBB+ } \\
\text { INHBC+ }\end{array}$ & $\begin{array}{l}\text { INHA+ } \\
\text { INHBA+ } \\
\text { INHBB+ } \\
\text { INHBC+ }\end{array}$ & $\begin{array}{l}\mathrm{INHA}+ \\
\mathrm{INHBA}+ \\
\mathrm{INHBB}+ \\
\mathrm{INHBC}+\end{array}$ & $\begin{array}{l}\text { INHA } \pm \\
\text { INHBA+ } \\
\text { INHBB+ } \\
\text { INHBC+ }\end{array}$ \\
\hline
\end{tabular}

+ readily detectable signal; ++ the signal is more intense than other positive cells; \pm a faint signal; - no signal; $N_{\text {the }}$ signal is detected in the cell nucleus; ${ }^{*}$ varying signal intensity across the cell population within tubule cross-sections; *signal intensity varies with the cycle of the seminiferous epithelium.

mouse. It provides baseline data that give insight into the roles of these proteins in normal testicular development and will assist future studies of these parameters in genetically modified or experimentally manipulated mice that exhibit perturbed testis function or altered spermatogenesis.

Activins and inhibins are involved in local actions that influence spermatogenic development and also participate in endocrine feedback regulation of the gonadotrophic hormone, FSH. Figure 7 illustrates the testicular protein levels of activin, inhibin and FST in relation to key spermatogenic events during mouse post-natal testis development. Here, inhibin levels are presented as amount per Sertoli cell, using previously published Sertoli cell numbers (Vergouwen et al. 1993), as it is widely understood that within the testis, inhibin is exclusively produced by the Sertoli cells (Steinberger 1979, Le Gac \& de Kretser 1982). The changing concentrations and localisation of these proteins within the testis indicate precise temporal changes that point to a significant degree of regulation through mechanisms that are yet to be identified.

Much more is known concerning the changes in the testicular and circulating levels of the inhibins in other species through the measurements of inhibin A and B by the use of specific ELISAs. Unfortunately, the current ELISAs do not function for murine samples and hence we report total immunoactive inhibin measurements obtained using an assay that measures both inhibin $A$ and $B$, and cross-reacts significantly with products of the $\alpha$ subunit (Robertson et al. 1988). Total testicular levels of inhibin in the mouse rise from $0 \mathrm{dpp}$ to a peak at 4 dpp, with a subsequent plateau to day 16 that is followed by a subsequent decline; this parallels the pattern of changing inhibin $\mathrm{B}$ testis concentrations in the rat (Buzzard et al. 2004). The rise and plateau reflect a period of Sertoli cell proliferation in both species that culminates in the formation of a stable, non-mitotic Sertoli cell population. It is accepted that the total number of Sertoli cells achieved at this time determines 

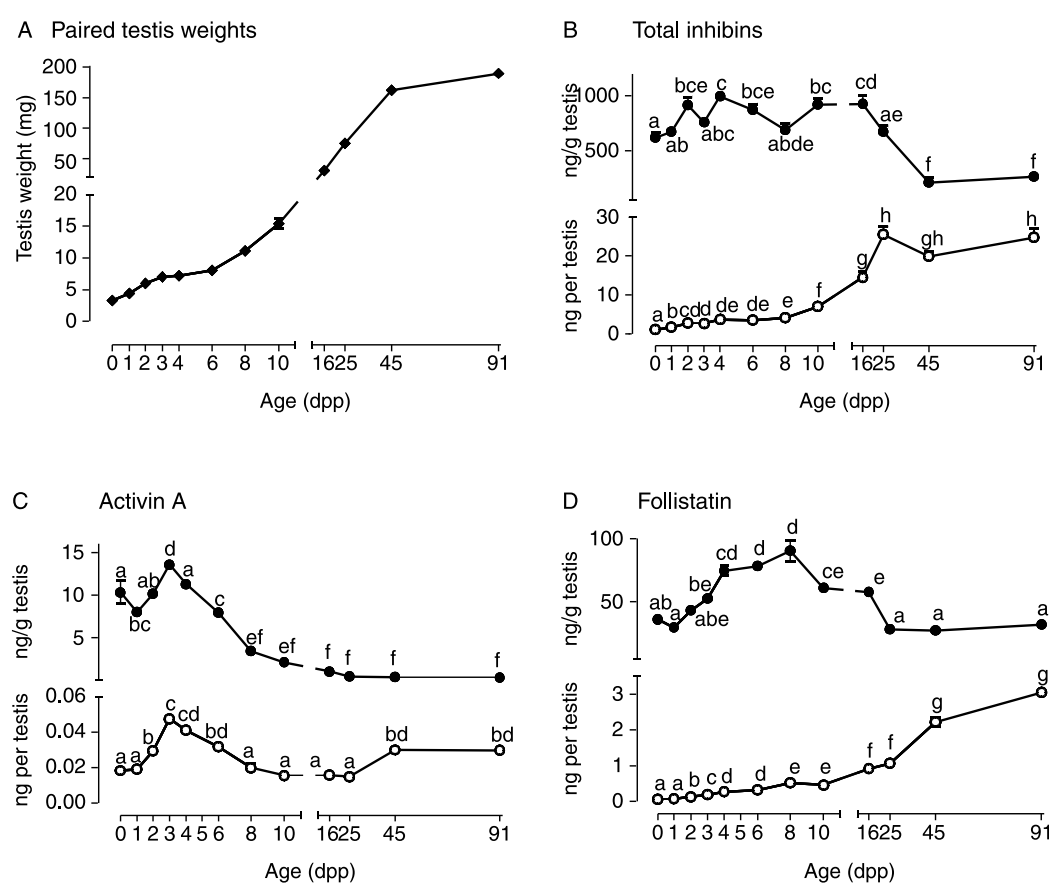
Figure 5 Paired testis weights and testicular levels of proteins in mouse post-natal development. (A) Paired testis weights and (B) testicular concen- trations (ng/g testis; - -) of total inhibins, (C) activin A and (D) follistatin proteins are shown. Total testicular production (ng/testis) for each protein is represented as $\bigcirc$. Data are shown as mean \pm s.E.M. of $n=6$ or more per group. Different letters at each point represent statistically significant data (refer to results section for $P$ values).

the germ cell content and spermatogenic capacity of the adult testis, which in turn is reflected in the secreted levels of inhibin B.

In both the mouse and rat, there is a progressive rise in the testis inhibin content, stimulated by rising levels of FSH associated with the onset of sexual maturation. In the rat, this is also reflected in rising levels of inhibin B in serum (Sharpe et al. 1999, Buzzard et al. 2004), but surprisingly, in the mouse, the inhibin levels in the circulation do not rise to reflect the increased total testis inhibin content. The reason for this difference is unclear, as all other species such as sheep, sub-human primates and human show a parallel rise in serum inhibin and FSH levels associated with pubertal maturation. This is viewed as establishment of a new set point for the negative feedback relationship between inhibin and FSH in the adult mammal (Marson et al. 1991, Andersson et al. 1997, Kondo et al. 2000, Sanford et al. 2000, Crofton et al. 2002). Humans exhibit two distinct phases of Sertoli cell mitotic divisions, one during the first year of birth and then again at the onset of puberty, each associated with increased FSH stimulation (Andersson et al. 1997, Crofton et al. 2002, O'Connor \& De Kretser 2004, Radicioni et al. 2005). In mice, however, our data show that FSH levels are the lowest during the period of Sertoli cell proliferation and increase after Sertoli cell maturation, with the negative relationship to inhibin established shortly after birth. This difference between humans and mice has been attributed to the measurable period of separation between post-natal and pubertal periods in humans, which does not exist in mice; spermatogenesis starts several years after birth in humans but begins within a few days after birth in mice. The FSH profile observed in the mice reflects its changing physiological role, from a mitogen acting on proliferating Sertoli cells during early post-natal development (Orth et al. 1988, Boitani et al. 1995, Meehan et al. 2000, Buzzard et al. 2003, Johnston et al. 2004, Meachem et al. 2005), to a stimulant on terminally differentiated Sertoli cells, ensuring the survival of germ cells and sperm production (Culler \& Negro-Vilar 1988, Rivier et al. 1988, McLachlan et al. 1995, Meachem et al. 1998).

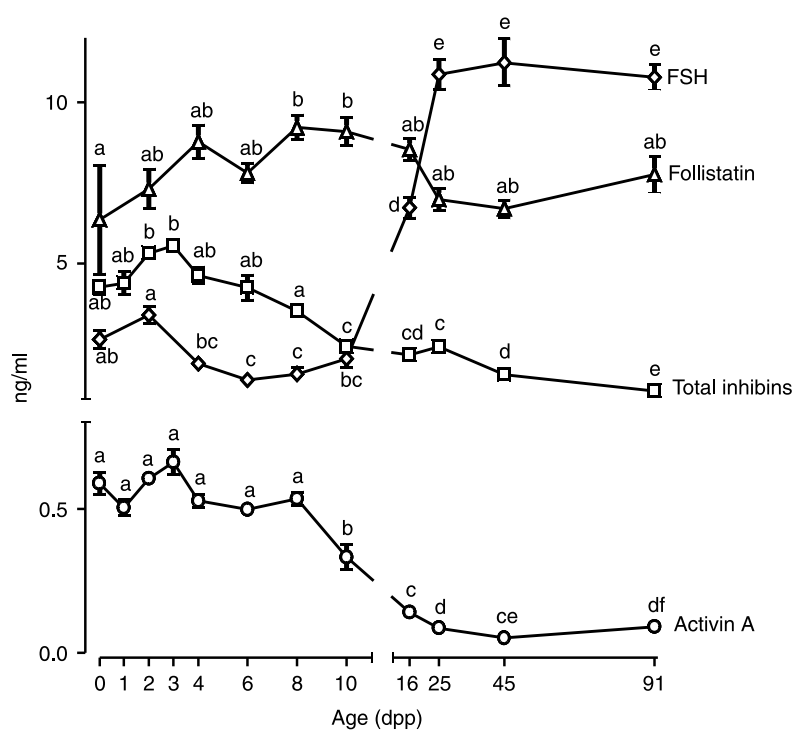

Figure 6 Levels of circulating hormones in mouse post-natal development. Serum hormone levels in mice are represented with respect to their age: $(\diamond) \mathrm{FSH} ;(\triangle)$ follistatin; $(\square)$ total inhibins; and $(\bigcirc)$ activin A (refer to Materials and Methods for numbers of mice). Data are shown as mean \pm S.E.M. of $n=6$ or more per group. Different letters on each line graph represent statistically significant data (refer to results section for $P$ values). 


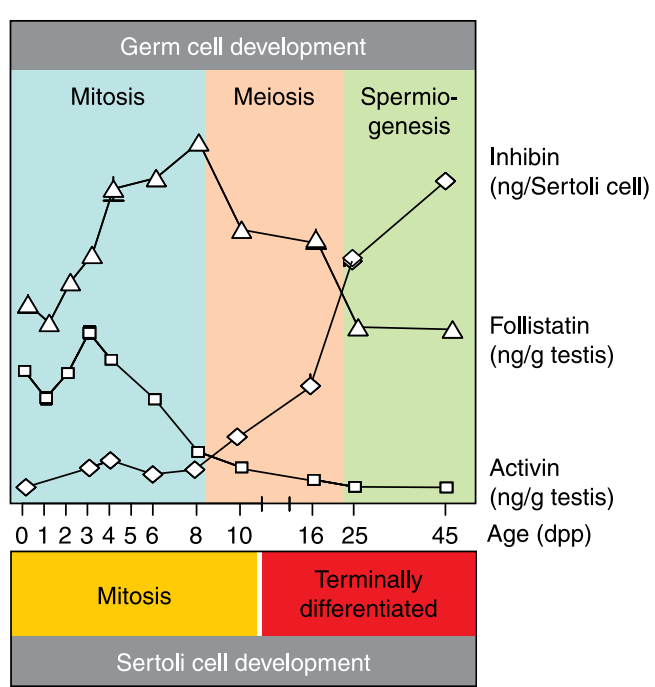

Figure 7 Modulation of testicular activin, inhibin and follistatin correspond with key spermatogenic events during mouse post-natal development. The activin and follistatin profiles expressed as ng/g testis are those presented in Fig. 5. Based on the assumption that inhibin is exclusively produced by Sertoli cells, inhibin values are presented as amount (ng) per Sertoli cell. Germ cells undergo three distinct developmental phases during spermatogenesis: mitosis, meiosis and spermiogenesis, the latter involving the morphological transformation of round spermatids to elongated mature spermatozoa. Sertoli cells are mitotically active during the phase of germ cell mitosis. They cease proliferation and enter terminal differentiation by around $11 \mathrm{dpp}$.

In accord with the results of studies in rats (Majdic et al. 1997) and humans (Anderson et al. 1998, Marchetti et al. 2003), the inhibin $\alpha$ subunit protein is detected primarily in Sertoli cells at all stages of post-natal development. Although this does not indicate the presence of dimeric inhibin, our observation of the $\beta_{B}$ subunit mRNA and protein in mouse Sertoli cells suggests that they have the capacity to produce inhibin $B$ and makes it highly likely that, in mice, the Sertoli cells are the major site of inhibin production. When Sertoli cells cease dividing, the inhibin concentration subsequently declined, evidently due to the dilution of Sertoli cell-derived products within the rapidly expanding germ cell population. On the other hand, total testicular production of inhibin significantly increased, indicating an increase in Sertoli cell activity, stimulated by high FSH levels.

Immunohistochemical analyses also revealed differential signal intensities for the inhibin $\alpha$ and $\beta_{B}$ subunit proteins in Sertoli cells of the juvenile and adult mouse testes, with the highest signal intensity discerned at stages X-III of the adult. This differential expression is understood to reflect the spatial and temporal cycling of Sertoli cells. Inhibin B production in rat seminiferous tubules was shown to be the greatest at comparable stages (Okuma et al. 2006). This cyclic pattern of inhibin production is consistent with the fact that germ cells have a direct influence on inhibin production that is mediated via secreted factors (Pineau et al. 1990, Clifton et al. 2002). The physiological significance of this regulation across stages of the seminiferous epithelium may be an indication of the tight regulation of activin activity at specific stages and cell types, in concert with the presence of other activin inhibitors such as FST and the $\beta_{C}$ subunit, to coordinate processes within the seminiferous epithelium. The regulation of activin activity by inhibin is also important during post-natal testis development as inhibin $\alpha$ null $\left(\right.$ Inha $\left.{ }^{-1}\right)$ mice develop visible stromal cell tumours at 4 weeks of age (Matzuk et al. 1992) mediated by the uninhibited actions of activin (Coerver et al. 1996, Li et al. 2007). In general, the modulation of inhibin expression during mouse spermatogenesis highlights its importance in maintaining testicular homeostasis.

In situ hybridisation and immunohistochemistry are only specific to the individual inhibin subunits being investigated and do not reveal the presence of dimeric proteins. However, these techniques identify the sites of cellular expression and hence possible sites of protein production. While the $\beta_{B}$ subunit mRNA was detected in spermatogonia, spermatocytes and spermatids of developing and adult mouse testes, the encoded protein was only observed in spermatogonia and spermatocytes of the immature testis but not in the adult. As inhibin $\alpha$ subunit protein was only observed in Sertoli cells, it is likely that $\beta_{\mathrm{B}}$ subunit expression in germ cells reflects activin $B$ production. It follows then that activin $B$ may be important in the regulation of immature germ cell development but not in adult spermatogenesis, a prospect that correlates with the observation of lower $\beta_{\mathrm{B}}$ mRNA levels in the adult testis. Although male $\beta_{\mathrm{B}}$ null $\left(I n h b b^{-/-}\right)$mice exhibit normal fertility (Vassalli et al. 1994), a histological examination of their immature testes was not reported. It is possible that the $\beta_{A}$ subunit compensates functionally for the absence of the $\beta_{B}$ subunit in this model, explaining its normal fertility phenotype. Currently, there is no assay available to measure activin B levels, and so the physiological relevance of activin $B$ remains to be determined. Our observation of $\beta_{B}$ subunit in adult Sertoli and Leydig cells agrees with published data on adult rat testes (Majdic et al. 1997, Buzzard et al. 2004) and human testes (Anderson et al. 1998). Only one report (Marchetti et al. 2003) observed the $\beta_{B}$ subunit protein in human pachytene spermatocytes and round spermatids but not in Sertoli cells. Although these discrepancies may be attributed to differences in tissue fixation and antigen retrieval, they may also reflect differential synthesis of inhibin and activin between the species.

Serum levels of activin A observed in this present study of mice mimicked the profile reported previously for rats (Buzzard et al. 2004), but its physiological significance remains unknown. While the source of circulating inhibin is predominantly the testis, the source of activin is ubiquitous, being synthesised by a large number of 
tissues (Meunier et al. 1988b). Furthermore, activin is widely viewed as a paracrine, rather than endocrine, regulator of cellular development (Welt \& Crowley 1998). Hence, the following discussion will focus on the correlation between testicular activin levels and its cellular localisation with physiological events.

In vitro studies of rat testes have shown that activin plays a key role in Sertoli cell proliferation (de Winter et al. 1993, Boitani et al. 1995, Brown et al. 2000, Fragale et al. 2001, Wreford et al. 2001, Buzzard et al. 2003). We observed the $\beta_{A}$ subunit mRNA and protein in mouse Sertoli cells and peritubular myoid cells throughout testis development. While the effect of activin on peritubular myoid cell growth has not been reported, peritubular myoid cells have been shown to secrete activin A in vitro and act in a paracrine fashion on Sertoli cells, inducing their production of inhibin and transferrin (de Winter et al. 1994). These data, along with our observations of elevated activin levels during the period of Sertoli cell proliferation, suggest that activin has both autocrine and paracrine actions on Sertoli cells during mouse testis development. This is supported by the finding that mice deficient in the activin type II receptor (Matzuk et al. 1995b) and mice with reduced activin bioactivity (Brown et al. 2000) have smaller testis size, indicative of reduced Sertoli cell numbers. Similarly, over-expression of the activin antagonists, FST and FST-like 3 (FSTL3), results in reduced testicular size in mice (Guo et al. 1998, Xia et al. 2004). Testes from both of these transgenic lines contained degenerating tubules devoid of germ cells and produced significantly less sperm, suggesting that germ cell development is compromised when activin activity is reduced.

Leydig cells also produce inhibin and activin subunits. We report here that both $\beta_{\mathrm{A}}$ and $\beta_{\mathrm{B}}$ subunit mRNAs and proteins are present in Leydig cells during post-natal testis development. Inhibin $\alpha$ subunit protein was also observed in Leydig cells, with stronger staining at $0 \mathrm{dpp}$ than at older ages. Majdic et al. (1997) also reported expression of inhibin $\alpha$ and $\beta_{B}$ subunit proteins in Leydig cells of rat testes, with decreasing signal intensity from birth to adulthood. Furthermore, adult rat Leydig cells have been reported to secrete bioactive and immunoreactive inhibin in vitro in response to LH (Drummond et al. 1989, Risbridger et al. 1989), and normal men administered with human chorionic gonadotrophin (hCG) had in increase in blood levels of pro- $\alpha \mathrm{C}$ (free $\alpha$ subunit) but not inhibin B (Kinniburgh \& Anderson 2001). These data imply that Leydig cells produce inhibin, although it is not secreted into circulation as inhibin B. Other lines of evidence indicate that Leydig cell inhibin plays autocrine and/or paracrine functions. In cultures of Leydig cells isolated from $21 \mathrm{dpp}$ rats, inhibin was found to stimulate testosterone production and antagonise the testosteronesuppressive effects of activin A (Hsueh et al. 1987). Subsequent studies on adult Leydig cells, however, did not identify testosterone-stimulating actions of inhibin.
While inhibin alone did not influence testosterone production, it did effectively block activin suppression of testosterone production by adult Leydig cells (Lin et al. 1989, Risbridger et al. 1989). These data suggest that some functions of inhibin may be age specific or they may relate in cell culture studies to the levels of endogenous production, which we have highlighted are dynamic throughout testicular development.

Because androgens are important regulators of Leydig cell development and function, it may be hypothesised that activin and inhibin influence Leydig cell development through the steroidogenic pathway. However, while testes from mice with reduced activin bioactivity, including ActRII knockout mice (Matzuk et al. 1995b), FST transgenic mice (Guo et al. 1998) and FSTL3 transgenic mice (Xia et al. 2004), have increased Leydig cells numbers, their $\mathrm{LH}$ and testosterone levels remain similar to those in wild-type animals. Only one FSTL3 transgenic mouse line showed elevated testosterone levels at $21 \mathrm{dpp}$ and reduced testosterone levels at adulthood (Xia et al. 2004). Hence, activin may act as a negative regulator of Leydig cell proliferation, independent of its effects on androgen production. Inhibin also negatively influences Leydig cell proliferation in synergy with Mullerian Inhibiting Substance (MIS), as mice deficient in both inhibin $\alpha$ and MIS display an earlier and more aggressive onset of Leydig cell neoplasia than do their respective homozygote knockouts (Matzuk et al. 1995a). In summary, our observation of the activin/ inhibin subunits in Leydig cells is in agreement with current data on their autocrine and paracrine regulation of Leydig cell function and proliferation.

We observed the localisation of $\beta_{\mathrm{A}}$ mRNA and protein in spermatogonia and spermatocytes of immature and adult mouse testes, but the ability of activin to regulate these cells depends on the expression of the activin receptors. The activin type II receptor mRNA has been shown to be expressed by Sertoli and germ cells (spermatogonia to round spermatids) of immature and adult rat testes (de Winter et al. 1992, Fragale et al. 2001), and one report shows both type IIB and type I activin receptor mRNAs are synthesised by immature murine spermatogonia and Sertoli cells (Puglisi et al. 2004), suggesting that activin may mediate both autocrine and paracrine regulation of both cell types.

The frequent sampling during the first week post partum which is a feature of this study enabled the identification of significant changes in testicular activin A concentrations, suggesting a tight modulation of activin signalling during this period. First, activin A concentrations significantly declined between 0 and $1 \mathrm{dpp}$ coinciding with the start of gonocyte proliferation and comparable with the decline observed in the rat between 0 and $3 \mathrm{dpp}$ (Buzzard et al. 2004). Subsequently, activin levels rose to peak at $3 \mathrm{dpp}$, after which the first spermatogonial stem cells appear (de Rooij 1998, McLean et al. 2003, Yoshida et al. 2004). These observations suggest a dual role of activin regulation 
on gonocyte development, where a reduction in local activin concentration is required for gonocytes to exit from their state of G1 arrest, while subsequent elevation in activin levels suggests a role in promoting gonocyte proliferation. The role of activin as an inducer of mitotic arrest in gonocytes is evident in the elevated gonocyte numbers in testes of newborn mice lacking the $\beta_{\mathrm{A}}$ subunit (Inhba ${ }^{-1-}$; Loveland et al. 2005). Subsequently, the role of activin as a mitogen is reflected in a study of 3-day-old rat testis fragment cultures, which showed that increased activin levels induced the proliferation of gonocytes (Meehan et al. 2000). In the present study, the observation of the $\beta_{\mathrm{A}}$ subunit protein in a subset of gonocytes and a more general localisation of the $\beta_{B}$ subunit in gonocytes supports the regulatory action of activins on these cells, but of course it may also influence the Sertoli cell population in which they are embedded.

Activin levels decrease after the differentiation of gonocytes into spermatogonia concordant with a rise of FST and inhibin testicular concentrations, both of which can inhibit the biological actions of both activin A and B. An increase of FST protein within spermatogonia and Sertoli cells of the immature rat testis has been previously described (Meehan et al. 2000). The rapid downregulation of activin activity would be envisioned to limit its mitogenic actions on gonocytes and Sertoli cells. This suggests that there is a need to inhibit activin bioactivity to enable gonocytes to differentiate into spermatogonia (Meehan et al. 2000) and to allow proliferation of spermatogonia, as activin has been shown to suppress the proliferative actions of $\mathrm{FSH}$ specifically on differentiating type A spermatogonia (Boitani et al. 1995). Furthermore, over-expression of the $\beta_{\mathrm{A}}$ subunit in juvenile mouse testes caused degeneration of spermatocytes and resulted in sterility (Tanimoto et al. 1999). Considered together with our reported observation of elevated $\beta_{C}$ subunit mRNAs in the mouse testis at the time of meiosis, the available data indicate that reduced activin bioactivity is required for spermatogonial proliferation and differentiation.

The expression of the $\beta_{\mathrm{A}}$ subunit in the nucleus of spermatocytes at $15 \mathrm{dpp}$ and adult age is in agreement with a previous report (Blauer et al. 1999), but its role at this stage is unknown. Similarly, the $\beta_{B}$ subunit detected in primary spermatocytes is noted and may be related to the influence of activin action on the morphology of mitochondria in these cells and their changing role in metabolism (Meinhardt et al. 2000). The emerging picture of regulated production and action of activin throughout testis development is in accord with its function as a key governor of testis growth.

While the role of the $\beta_{\mathrm{C}}$ subunit in testis development is uncertain at this time, it has been reported to function as a dominant negative regulator of activin A activity by sequestering the $\beta_{\mathrm{A}}$ subunit to produce the activin $\mathrm{AC}$ heterodimer (Mellor et al. 2003), and hence local activin A bioavailability may be limited by co-expression of both $\beta_{\mathrm{C}}$ and $\beta_{\mathrm{A}}$ subunits. We have shown that both are present in Sertoli and Leydig cells in immature and adult testes, as well as in spermatocytes and elongating spermatids of the adult mouse. However, while the $\beta_{\mathrm{A}}$ subunit protein was evident in the nucleus of primary spermatocytes, the $\beta_{C}$ subunit protein, which also encodes a nuclear localisation signal (Lau et al. 1996), was selectively observed at a later developmental stage in the nucleus of round spermatids. It is therefore possible that the $\beta_{C}$ subunit performs additional roles, independent of antagonising $\beta_{\mathrm{A}}$ signalling activity.

In summary, this study has documented that the levels of activins, inhibins, FST and FSH are highly modulated during mouse testis development, and changes in mRNA and protein levels correlate with shifts in Sertoli cell maturation and phases of germ cell development. In addition, the inhibin/activin subunit mRNAs and proteins exhibit discrete and overlapping cellular localisation patterns during the course of testis development and in the adult testis. The rapid changes in levels of activin $A$ and its negative regulators during the onset of the first wave of spermatogenesis highlights the importance of understanding the regulation and control of activin signalling. Our data show this may occur through the dynamic synthesis of FST, inhibin $\alpha$ - and inhibin/activin $\beta_{C}$-subunit proteins. This is the first comprehensive assessment of cellular production of activins, inhibin, FST and FSH levels in the developing mouse testis. These data offer a rigorous platform for further studies of the roles of these proteins during normal and perturbed testis growth throughout the first wave of spermatogenesis.

\section{Materials and Methods}

\section{Animals and tissue collection}

Testes used for RNA and protein isolation and serum samples were obtained from C57BL/6xCBA F1 male mice aged 0, 1, 2, $3,4,6,8,10,16,26,42$ and 91 days post partum (dpp). These mice were housed at Monash University Central Animal Services (MAS) under a 12-h light cycle. Ovarian and hepatic tissue used for RNA isolation (providing controls for real-time PCR studies) were obtained from Swiss mice housed at MAS. Testes used for histological analysis were obtained from Swiss mice housed at the University of Newcastle Central Animal Facility. The day of birth was noted as $0 \mathrm{dpp}$. Mice up to the age of 16 days were decapitated and blood immediately collected using a Microvette CB 300 capillary tube (Sarstedt, Germany). Older mice were killed by $\mathrm{CO}_{2}$ asphyxiation and blood collected via cardiac puncture. Blood samples were centrifuged at $7500 \mathrm{~g}$ for 20 mins, and serum was collected and stored at $-20{ }^{\circ} \mathrm{C}$.

For RNA isolation and testes protein homogenates, testes were decapsulated, weighed, snap frozen and stored at $-80^{\circ} \mathrm{C}$ until use. For in situ hybridisation, testes were immediately placed in Bouin's fixative, and after $5 \mathrm{~h}$ they were washed several times in $70 \%$ ethanol and processed as described below. All investigations 
conformed to the NHMRC/CSIRO/AAC Code of Practice for the Care and Use of Animals for Experimental Purposes and were approved by the Monash University Standing Committee on Ethics in Animal Experimentation and by the University of Newcastle Animal Care and Ethics Committee.

\section{Quantitative mRNA analysis}

Total RNA from mouse testes was extracted using TRIzol reagent (Invitrogen) and treated with DNA-free (Ambion, Austin, TX, USA) according to the manufacturer's specifications. Three independent tissue samples were used to prepare RNA samples for each time point. Each 0 dpp RNA sample was made from a pool of eight testes, each $4 \mathrm{dpp}$ RNA sample from a pool of six testes, 6-16 dpp from a pool of four testes, and 26 and $42 \mathrm{dpp}$ from a pool of three testes. Two micrograms of DNA-free RNA were used to generate cDNA using Superscript III reverse transcriptase (RT) (Life Technologies) with oligo-dT primers, according to the enzyme manufacturer's guidelines. Negative control RT samples lacking Superscript III (-RT) were included for each sample. PCR samples were prepared using Power SYBR-Green PCR master mix (Applied Biosystems, Foster City, CA, USA) and the gene-specific primers listed in Table 2. PCR was performed in the Applied Biosystems 7900HT Analyzer (Applied Biosystems) using the following cycling conditions: denaturation at $95{ }^{\circ} \mathrm{C}$ for $10 \mathrm{~min}$; amplification for 40 cycles of $95{ }^{\circ} \mathrm{C}$ for $15 \mathrm{~s}, 62^{\circ} \mathrm{C}$ for $30 \mathrm{~s}$ and $72{ }^{\circ} \mathrm{C}$ for $30 \mathrm{~s}$. Each sample was analysed in triplicate and quantification performed using the Pfaffl equation (Pfaffl 2001) relative to levels of actin (Actb) mRNA. The values were then normalised to the value at $0 \mathrm{dpp}$, which was arbitrarily set to 1 . Water and - RT samples were included as negative controls. PCR products were verified by sequencing.

\section{In situ hybridisation}

In situ hybridisation using digoxygenin (DIG)-labelled cRNAs was used to localise mRNAs encoding Inhba and Inhbb in Swiss mouse testis sections as previously described (Meehan et al. 2000). Briefly, Bouin's fixed testes were embedded in paraffin and cut into $4 \mu \mathrm{m}$ sections. Using the primers in Table 2, probes were prepared from cDNA templates and their specificity verified using sequencing and Northern blot analyses. Sense and anti-sense DIG-labelled cRNAs for each target sequence were made from purified PCR products (QIAquick PCR Purification Kit; QIAGEN) using RNA polymerises T7 and SP6 (Promega) and the DIG-labelling kit (Roche) according to the manufacturer's instructions.
Hybridisation was performed overnight at the following probe concentration and temperature for each target sequence: $1 \mu \mathrm{g} / \mathrm{ml}$ and $50{ }^{\circ} \mathrm{C}$ for Inhba and $1 \mu \mathrm{g} / \mathrm{ml}$ and $55^{\circ} \mathrm{C}$ for Inhbb. The probes were detected with anti-DIG antibody (Roche) and visualised using 5-Bromo-4-chloro-3-indolyl phosphate/Nitroblue tetrazolium (BCIP/NBT; Astral Scientific, Sydney, Australia). The sections were counterstained with Harris haematoxylin (Sigma Chemical Co.) and mounted in GVA aqueous mounting solution (Invitrogen). In every experiment, on every sample, the sense cRNA was included in parallel with the anti-sense cRNA as a negative control.

For these studies and also for immunohistochemisty, the qualitative assessment of cellular localisation was performed on at least seven different tubule cross-sections from three different animals for ages 0 and $3 \mathrm{dpp}$, and at least six different tubule cross-sections of each stage of the seminiferous epithelium from at least two different animals for ages $15 \mathrm{dpp}$ and adult.

\section{Immunohistochemistry}

Immunolocalisation, using antibodies to INHBA $(\# 153+154$ anti-cyclic activin $\beta_{\mathrm{A}}(81-113)-\mathrm{NH}_{2}$ rabbit polyclonal) and INHBB (\#197 anti-cyclic activin $\beta_{\mathrm{B}}(80-112)-\mathrm{NH}_{2}$ rabbit polyclonal; gifts from Wylie Vale at the SALK Institute; Meunier et al. 1988a, Roberts et al. 1989, Vaughan et al. 1989, Bilezikjian et al. 1993), INHBC (anti-activin $\beta_{C}$ Clone-1; Mellor et al. 2000) and INHA (anti-inhibin $\alpha$ subunit R1; Serotec, Oxford, UK) were detected using the DAKO Autostainer Universal Staining System (DAKO, Glostrup, Denmark) as previously described (Gold et al. 2004). Microwave antigen retrieval was carried out in $0.01 \mathrm{M}$ citrate buffer $(\mathrm{pH} \mathrm{6.0)}$ ) for INHBA, INHBB and INHA and 0.01 Mglycine buffer ( $\mathrm{pH} 4.5)$ for INBBC. Sections were treated with CAS Blocking Reagent (DAKO), antibodies detected with avidin-biotin complex $(\mathrm{ABC})$ and a colour reaction product developed following addition of 3,3'-diaminobenzidine tetrahydrochloride (DAB; DAKO). Negative controls were immunoglobulins (IgG) matched to the primary antibody, rabbit $\operatorname{lgG}(\mathrm{DAKO})$ for INHBA and INHBB, IgG2a (DAKO) for INHA and IgG1 (DAKO) for INHBC.

\section{Serum and testicular extracts}

To have sufficient serum for use in the hormone assays, equal volumes of serum from several animals were pooled for the 0-16 dpp groups as follows. The numbers of mice sampled per pool were five to eight mice for the $0 \mathrm{dpp}$ group, two to three mice for the 1, 4, 6, 8 and $16 \mathrm{dpp}$ groups and four to five mice for the day 2 group. For 25, 43 and $91 \mathrm{dpp}$ groups, six to

Table 2 Primers used in real-time PCR.

\begin{tabular}{lllll}
\hline Gene name & Common name & Accession no. & Forward primer & Reverse primer \\
\hline Inha & Inhibin $\alpha$ & NM_010564 & $5^{\prime}$-ATGCACAGGACCTCTGAACC-3' & 5 $^{\prime}$-GGATGGCCGGAATACATAAG-3' \\
Inhba & Inhibin/activin $\beta_{\mathrm{A}}$ & NM_008380 & $5^{\prime}$-GGAGAACGGGTATGTGGAGA-3' & $5^{\prime}$-TGGTCCTGGTTCTGTTAGCC-3' \\
Inhbb & Inhibin/activin $\beta_{\mathrm{B}}$ & NM_008381 & $5^{\prime}$-CCTGAGTGAATGCACACCAC-3' & $5^{\prime}$-CGAGTCCAGTTCGCCTAGT-3' \\
Inhbc & Inhibin/activin $\beta_{\mathrm{C}}$ & NM_010565 & $5^{\prime}$-GACTCCAACCACAGTAGTGAAC-3' & $5^{\prime}$-CACTGGCCGACTGAGTATGG-3' \\
Fst & Follistatin & NM_008046 & $5^{\prime}$-AAAACCTACCGCAACGAATG-3' & $5^{\prime}$-TTCAGAAGAGGAGGGCTCTG-3 ${ }^{\prime}$ \\
Actb & Actin & NM_007393 & $5^{\prime}$-AGGCTGTGCTGTCCCTGTAT-3' & $5^{\prime}$-AAGGAAGGCTGGAAAAGAGC-3'
\end{tabular}


eight individual animals were used. For each age group, six to eight pooled samples were generated and analysed.

To generate testicular homogenates, paired testes from the same mice used for the serum pools were decapsulated and homogenised in PBS on ice using a hand-held tissue homogeniser. The mass of testis per $\mathrm{ml}$ of PBS for homogenates was $60 \mathrm{mg}$ tissue per $\mathrm{ml}$ for 0-16 dpp pools and $200 \mathrm{mg} / \mathrm{ml}$ for 25-91 dpp groups. Homogenates were spun for $20 \mathrm{~min}$ at $10000 \mathrm{~g}$, and the supernatants were stored at $-80^{\circ} \mathrm{C}$. Final protein concentrations of the samples were matched to the protein content of the assay diluents.

\section{Hormone assays}

Serum FSH concentrations were determined using RIA reagents kindly provided by Dr A Parlow, NIDDK (Bethesda, MD, USA). The iodination preparation and antiserum used were $\mathrm{rFSH}$ I-8 and anti-rFSH-S-11 respectively and the results are expressed in terms of NIDDK mFSH-RP-1. Goat anti-rabbit IgG (GAR\#12; Monash Institute of Medical Research, Monash University, Melbourne, Australia) was used as second antibody. All measurements were performed on $20 \mu \mathrm{l}$ duplicates of serum. The lowest limit of detection was $1.14 \mathrm{ng} / \mathrm{ml}$, the average within-assay coefficient of variation (CV) was $7.4 \%$, and the inter-assay $\mathrm{CV}$ was $3.0 \%$ ( $n=3$ assays) calculated using a pool of normal mouse serum used in each assay.

The available ELISA assays for measuring inhibin A (Groome et al. 1994) and inhibin B (Groome et al. 1996) proteins do not detect these proteins in mice. Hence, inhibin levels were measured using a RIA with a rabbit antiserum (\#1989) directed to the $\alpha$ subunit and as such measures both inhibin $A$ and $B$ proteins and free inhibin $\alpha$ subunit (pro- $\alpha-C$; Robertson et al. 1988). Results are expressed in terms of $31 \mathrm{kDa}$ hr-inhibin, and iodinated hr-inhibin was used as tracer. Goat anti-rabbit IgG (GAR\#12) was used as second antibody. The average withinassay CV was $9.1 \%$ and the inter-assay $C V$ was $5.0 \% \quad(n=4$ assays). The lowest limit of detection was $0.22 \mathrm{ng} / \mathrm{ml}$.

FST concentrations were measured using a discontinuous RIA as described previously (O'Connor et al. 1999), which detects total FST using a dissociating reagent that dissociates the activin-FST complex. The samples were measured in a total of five assays, the average intra-assay CV was $10.1 \%$, the interassay CV was $6.2 \%$ and the limit of detection was $0.99 \mathrm{ng} / \mathrm{ml}$.

Activin A was measured using a specific ELISA (Knight et al. 1996) which exhibits minimal cross-reactivity with inhibin $A$ $(0.5 \%)$, and no significant cross-reactivity to other related proteins, according to the manufacturer's instructions (Oxford Bio-Innovations, Oxfordshire, UK) with some minor modifications as described previously (O'Connor et al. 1999). Protein concentrations in the serum and testis homogenates were matched to the BSA content in the assay diluent. For the serum assays, the average intra-plate CV was $5.4 \%$, the inter-plate CV was $7.0 \%$ ( $n=4$ plates) and the detection limit was $0.01 \mathrm{ng} / \mathrm{ml}$. For the testis homogenate assays, the average intra-plate $\mathrm{CV}$ was $7.6 \%$, the inter-plate CV was $9.7 \%(n=3$ plates $)$ and the detection limit was $0.01 \mathrm{ng} / \mathrm{ml}$. A mouse serum pool and a testis homogenate pool were each diluted in a dose-dependent manner, which was parallel to the standard curve in each assay (data not shown).

\section{Statistical analysis}

Data are represented as mean \pm s.E.M. All data were analysed using one-way ANOVA combined with Tukey's post-test for comparison between each age. Serum data were log transformed before ANOVA analysis. Data from groups with different letters were significantly different $(P<0.05)$. Correlation between inhibin and FSH was analysed using Pearson's test.

\section{Acknowledgements}

This study was supported by grants from the National Health and Research Council of Australia (\#384108 to K L and $\# 334011$ to $\mathrm{K} \mathrm{L}$ and DdK), the Australian Research Council (\#34829) and an Australian Postgraduate Award from the Australian Government to BB. Technical support was provided by Marilyn Bakker and Susan Hayward. Bouin's fixed Swiss mouse testes were kindly provided by Dr Shaun Roman at the University of Newcastle, Australia. The authors declare that there is no conflict of interest that would prejudice the impartiality of this scientific work

\section{References}

Anawalt BD, Bebb RA, Matsumoto AM, Groome NP, Illingworth PJ, McNeilly AS \& Bremner WJ 1996 Serum inhibin B levels reflect Sertoli cell function in normal men and men with testicular dysfunction. Journal of Clinical Endocrinology and Metabolism 81 3341-3345.

Anderson RA, Irvine DS, Balfour C, Groome NP \& Riley SC 1998 Inhibin B in seminal plasma: testicular origin and relationship to spermatogenesis. Human Reproduction 13 920-926.

Andersson AM, Juul A, Petersen JH, Muller J, Groome NP \& Skakkebaek NE 1997 Serum inhibin B in healthy pubertal and adolescent boys: relation to age, stage of puberty, and follicle-stimulating hormone, luteinizing hormone, testosterone, and estradiol levels. Journal of Clinical Endocrinology and Metabolism 82 3976-3981.

Au CL, Robertson DM \& de Kretser DM 1986 Measurement of inhibin and an index of inhibin production by rat testes during postnatal development. Biology of Reproduction 35 37-43.

Bilezikjian LM, Vaughan JM \& Vale WW 1993 Characterization and the regulation of inhibin/activin subunit proteins of cultured rat anterior pituitary cells. Endocrinology 133 2545-2553.

Blauer M, Husgafvel S, Syvala H, Tuohimaa P \& Ylikomi T 1999 Identification of a nuclear localization signal in activin/inhibin betaA subunit; intranuclear betaA in rat spermatogenic cells. Biology of Reproduction 60 588-593.

Boitani C, Stefanini M, Fragale A \& Morena AR 1995 Activin stimulates Sertoli cell proliferation in a defined period of rat testis development. Endocrinology 136 5438-5444.

Brown CW, Houston-Hawkins DE, Woodruff TK \& Matzuk MM 2000 Insertion of Inhbb into the Inhba locus rescues the Inhba-null phenotype and reveals new activin functions. Nature Genetics 25 453-457.

Buzzard JJ, Farnworth PG, De Kretser DM, O'Connor AE, Wreford NG \& Morrison JR 2003 Proliferative phase sertoli cells display a developmentally regulated response to activin in vitro. Endocrinology 144 474-483.

Buzzard JJ, Loveland KL, O'Bryan MK, O'Connor AE, Bakker M, Hayashi T, Wreford NG, Morrison JR \& de Kretser DM 2004 Changes in circulating and testicular levels of inhibin A and B and activin A during postnatal development in the rat. Endocrinology 145 3532-3541.

Clifton RJ, O'Donnell L \& Robertson DM 2002 Pachytene spermatocytes in co-culture inhibit rat Sertoli cell synthesis of inhibin beta B-subunit and inhibin B but not the inhibin alpha-subunit. Journal of Endocrinology 172 565-574. 
Coerver KA, Woodruff TK, Finegold MJ, Mather J, Bradley A \& Matzuk MM 1996 Activin signaling through activin receptor type Il causes the cachexialike symptoms in inhibin-deficient mice. Molecular Endocrinology 10 534-543.

Crofton PM, Evans AE, Groome NP, Taylor MR, Holland CV \& Kelnar CJ 2002 Inhibin B in boys from birth to adulthood: relationship with age, pubertal stage, FSH and testosterone. Clinical Endocrinology $\mathbf{5 6}$ 215-221.

Culler MD \& Negro-Vilar A 1988 Passive immunoneutralization of endogenous inhibin: sex-related differences in the role of inhibin during development. Molecular and Cellular Endocrinology 58 263-273.

Drummond AE, Risbridger GP \& de Kretser DM 1989 The involvement of Leydig cells in the regulation of inhibin secretion by the testis. Endocrinology 125 510-515.

Fragale A, Puglisi R, Morena AR, Stefanini M \& Boitani C 2001 Agedependent activin receptor expression pinpoints activin $A$ as a physiological regulator of rat Sertoli cell proliferation. Molecular Human Reproduction 7 1107-1114.

Le Gac F \& de Kretser DM 1982 Inhibin production by Sertoli cell cultures. Molecular and Cellular Endocrinology 28 487-498.

Gold EJ, O'Bryan MK, Mellor SL, Cranfield M, Risbridger GP, Groome NP \& Fleming JS 2004 Cell-specific expression of betaC-activin in the rat reproductive tract, adrenal and liver. Molecular and Cellular Endocrinology 222 61-69.

Groome NP, Illingworth PJ, O'Brien M, Cooke I, Ganesan TS, Baird DT \& McNeilly AS 1994 Detection of dimeric inhibin throughout the human menstrual cycle by two-site enzyme immunoassay. Clinical Endocrinology 40 717-723.

Groome NP, Illingworth PJ, O'Brien M, Pai R, Rodger FE, Mather JP \& McNeilly AS 1996 Measurement of dimeric inhibin B throughout the human menstrual cycle. Journal of Clinical Endocrinology and Metabolism 81 1401-1405.

Guo Q, Kumar TR, Woodruff T, Hadsell LA, DeMayo FJ \& Matzuk MM 1998 Overexpression of mouse follistatin causes reproductive defects in transgenic mice. Molecular Endocrinology 12 96-106.

Hashimoto O, Nakamura T, Shoji H, Shimasaki S, Hayashi Y \& Sugino H 1997 A novel role of follistatin, an activin-binding protein, in the inhibition of activin action in rat pituitary cells. Endocytotic degradation of activin and its acceleration by follistatin associated with cell-surface heparan sulfate. Journal of Biological Chemistry 272 13835-13842.

Hsueh AJ, Dahl KD, Vaughan J, Tucker E, Rivier J, Bardin CW \& Vale W 1987 Heterodimers and homodimers of inhibin subunits have different paracrine action in the modulation of luteinizing hormone-stimulated androgen biosynthesis. PNAS 84 5082-5086.

Itman C, Mendis S, Barakat B \& Loveland KL 2006 All in the family: TGF- $\beta$ family action in testis development. Reproduction 132 233-246.

Johnston H, Baker PJ, Abel M, Charlton HM, Jackson G, Fleming L, Kumar TR \& O'Shaughnessy PJ 2004 Regulation of Sertoli cell number and activity by follicle-stimulating hormone and androgen during postnatal development in the mouse. Endocrinology 145 318-329.

Kinniburgh D \& Anderson RA 2001 Differential patterns of inhibin secretion in response to gonadotrophin stimulation in normal men. International Journal of Andrology 24 95-101.

Knight PG, Muttukrishna S \& Groome NP 1996 Development and application of a two-site enzyme immunoassay for the determination of 'total' activin-A concentrations in serum and follicular fluid. Journal of Endocrinology 148 267-279.

Kondo M, Udono T, Jin W, Shimizu K, Funakoshi M, Itoh M, Watanabe G, Groome NP \& Taya K 2000 Changes in plasma concentrations of inhibin $A$ and inhibin B throughout sexual maturation in the male chimpanzee. Endocrine Journal 47 707-714.

de Kretser DM, Loveland KL, Meehan T, O'Bryan MK, Phillips DJ \& Wreford NG 2001 Inhibins, activins and follistatin: actions on the testis. Molecular and Cellular Endocrinology 180 87-92.

Kumar TR, Palapattu G, Wang P, Woodruff TK, Boime I, Byrne MC \& Matzuk MM 1999 Transgenic models to study gonadotropin function: the role of follicle-stimulating hormone in gonadal growth and tumorigenesis. Molecular Endocrinology 13 851-865.

Lau AL, Nishimori K \& Matzuk MM 1996 Structural analysis of the mouse activin beta C gene. Biochimica et Biophysica Acta 1307 145-148.
Lewis KA, Gray PC, Blount AL, MacConell LA, Wiater E, Bilezikjian LM \& Vale W 2000 Betaglycan binds inhibin and can mediate functional antagonism of activin signalling. Nature 404 411-414.

Li Q, Graff JM, O'Connor AE, Loveland KL \& Matzuk MM 2007 SMAD3 regulates gonadal tumorigenesis. Molecular Endocrinology 21 2472-2486.

Lin T, Calkins JK, Morris PL, Vale W \& Bardin CW 1989 Regulation of Leydig cell function in primary culture by inhibin and activin. Endocrinology 125 2134-2140.

Loveland KL, McFarlane JR \& de Kretser DM 1996 Expression of activin beta $\mathrm{C}$ subunit $\mathrm{mRNA}$ in reproductive tissues. Journal of Molecular Endocrinology 17 61-65.

Loveland KL, Hogarth C, Mendis S, Efthymiadis A, Ly J, Itman C, Meachem S, Brown CW \& Jans DA 2005 Drivers of germ cell maturation. Annals of the New York Academy of Sciences 1061 173-182.

Majdic G, McNeilly AS, Sharpe RM, Evans LR, Groome NP \& Saunders PT 1997 Testicular expression of inhibin and activin subunits and follistatin in the rat and human fetus and neonate and during postnatal development in the rat. Endocrinology 138 2136-2147.

Marchetti C, Hamdane M, Mitchell V, Mayo K, Devisme L, Rigot JM, Beauvillain JC, Hermand E \& Defossez A 2003 Immunolocalization of inhibin and activin alpha and betaB subunits and expression of corresponding messenger RNAs in the human adult testis. Biology of Reproduction 68 230-235.

Marson J, Meuris S, Cooper RW \& Jouannet P 1991 Puberty in the male chimpanzee: time-related variations in luteinizing hormone, folliclestimulating hormone, and testosterone. Biology of Reproduction 44 456-460.

Massa G, de Zegher F \& Vanderschueren-Lodeweyckx M 1992 Serum levels of immunoreactive inhibin, $\mathrm{FSH}$, and $\mathrm{LH}$ in human infants at preterm and term birth. Biology of the Neonate 61 150-155.

Mather JP, Moore A \& Li RH 1997 Activins, inhibins, and follistatins: further thoughts on a growing family of regulators. Proceedings of the Society for Experimental Biology and Medicine 215 209-222.

Matzuk MM, Finegold MJ, Su JG, Hsueh AJ \& Bradley A 1992 Alphainhibin is a tumour-suppressor gene with gonadal specificity in mice. Nature 360 313-319.

Matzuk MM, Finegold MJ, Mishina Y, Bradley A \& Behringer RR 1995a Synergistic effects of inhibins and mullerian-inhibiting substance on testicular tumorigenesis. Molecular Endocrinology 9 1337-1345.

Matzuk MM, Kumar TR \& Bradley A 1995b Different phenotypes for mice deficient in either activins or activin receptor type II. Nature 374 356-360.

Matzuk MM, Lu N, Vogel H, Sellheyer K, Roop DR \& Bradley A 1995C Multiple defects and perinatal death in mice deficient in follistatin. Nature 374 360-363.

McCarrey JR 1993 Development of the germ cell. In Cell and Molecular Biology of the Testis, pp 58-89. Eds C Desjardins \& LL Ewing. New York: Oxford University Press.

McLachlan RI, Wreford NG, de Kretser DM \& Robertson DM 1995 The effects of recombinant follicle-stimulating hormone on the restoration of spermatogenesis in the gonadotropin-releasing hormone-immunized adult rat. Endocrinology 136 4035-4043.

McLean DJ, Friel PJ, Johnston DS \& Griswold MD 2003 Characterization of spermatogonial stem cell maturation and differentiation in neonatal mice. Biology of Reproduction $692085-2091$.

Meachem SJ, Wreford NG, Stanton PG, Robertson DM \& McLachlan RI 1998 Follicle-stimulating hormone is required for the initial phase of spermatogenic restoration in adult rats following gonadotropin suppression. Journal of Andrology 19 725-735.

Meachem SJ, Ruwanpura SM, Ziolkowski J, Ague JM, Skinner MK \& Loveland KL 2005 Developmentally distinct in vivo effects of FSH on proliferation and apoptosis during testis maturation. Journal of Endocrinology 186 429-446.

Meehan T, Schlatt S, O'Bryan MK, de Kretser DM \& Loveland KL 2000 Regulation of germ cell and Sertoli cell development by activin, follistatin, and FSH. Developmental Biology $220225-237$.

Meinhardt A, McFarlane JR, Seitz J \& de Kretser DM 2000 Activin maintains the condensed type of mitochondria in germ cells. Molecular and Cellular Endocrinology 168 111-117.

Mellor SL, Cranfield M, Ries R, Pedersen J, Cancilla B, de Kretser D, Groome NP, Mason AJ \& Risbridger GP 2000 Localization of activin 
beta(A)-, beta(B)-, and beta $(\mathrm{C})$-subunits in humanprostate and evidence for formation of new activin heterodimers of beta(C)-subunit. Journal of Clinical Endocrinology and Metabolism 85 4851-4858.

Mellor SL, Ball EM, O'Connor AE, Ethier JF, Cranfield M, Schmitt JF, Phillips DJ, Groome NP \& Risbridger GP 2003 Activin betaC-subunit heterodimers provide a new mechanism of regulating activin levels in the prostate. Endocrinology 144 4410-4419.

Meunier H, Cajander SB, Roberts VJ, Rivier C, Sawchenko PE, Hsueh AJ \& Vale W 1988a Rapid changes in the expression of inhibin alpha-, beta A-, and beta B-subunits in ovarian cell types during the rat estrous cycle. Molecular Endocrinology 2 1352-1363.

Meunier H, Rivier C, Evans RM \& Vale W $1988 b$ Gonadal and extragonadal expression of inhibin alpha, beta $A$, and beta $B$ subunits in various tissues predicts diverse functions. PNAS 85 247-251.

Muttukrishna S, North RA, Morris J, Schellenberg JC, Taylor RS, Asselin J, Ledger W, Groome N \& Redman CW 2000 Serum inhibin A and activin A are elevated prior to the onset of pre-eclampsia. Human Reproduction 15 1640-1645.

O'Connor AE \& De Kretser DM 2004 Inhibins in normal male physiology. Seminars in Reproductive Medicine 22 177-185.

O'Connor AE, McFarlane JR, Hayward S, Yohkaichiya T, Groome NP \& de Kretser DM 1999 Serum activin A and follistatin concentrations during human pregnancy: a cross-sectional and longitudinal study. Human Reproduction 14 827-832.

Okuma Y, O'Connor AE, Hayashi T, Loveland KL, de Kretser DM \& Hedger MP 2006 Regulated production of activin A and inhibin B throughout the cycle of the seminiferous epithelium in the rat. Journal of Endocrinology 190 331-340.

Orth JM 1993 Cell biology of testicular development in the fetus and neonate. In Cell and Molecular Biology of the Testis, pp 3-42. Eds $C$ Desjardins \& LL Ewing. New York: Oxford University Press.

Orth JM, Gunsalus GL \& Lamperti AA 1988 Evidence from Sertoli celldepleted rats indicates that spermatid number in adults depends on numbers of Sertoli cells produced during perinatal development. Endocrine Journal 122 787-794.

Pfaffl MW 2001 A new mathematical model for relative quantification in real-time RT-PCR. Nucleic Acids Research 29 e45.

Pineau C, Sharpe RM, Saunders PT, Gerard N \& Jegou B 1990 Regulation of Sertoli cell inhibin production and of inhibin alpha-subunit mRNA levels by specific germ cell types. Molecular and Cellular Endocrinology 72 13-22.

Puglisi R, Montanari M, Chiarella P, Stefanini M \& Boitani C 2004 Regulatory role of BMP2 and BMP7 in spermatogonia and Sertoli cell proliferation in the immature mouse. European Journal of Endocrinology 151 511-520.

Radicioni AF, Anzuini A, De Marco E, Nofroni I, Castracane VD \& Lenzi A 2005 Changes in serum inhibin B during normal male puberty. European Journal of Endocrinology 152 403-409.

Risbridger GP, Clements J, Robertson DM, Drummond AE, Muir J, Burger HG \& de Kretser DM 1989 Immuno- and bioactive inhibin and inhibin alpha-subunit expression in rat Leydig cell cultures. Molecular and Cellular Endocrinology 66 119-122.

Rivier C, Cajander S, Vaughan J, Hsueh AJ \& Vale W 1988 Age-dependent changes in physiological action, content, and immunostaining of inhibin in male rats. Endocrinology 123 120-126.

Roberts V, Meunier H, Sawchenko PE \& Vale W 1989 Differential production and regulation of inhibin subunits in rat testicular cell types. Endocrinology 125 2350-2359.

Robertson DM, Hayward S, Irby D, Jacobsen J, Clarke L, McLachlan RI \& de Kretser DM 1988 Radioimmunoassay of rat serum inhibin: changes after PMSG stimulation and gonadectomy. Molecular and Cellular Endocrinology 58 1-8.

de Rooij DG 1998 Stem cells in the testis. International Journal of Experimental Pathology 79 67-80.

de Rooij DG \& Russell LD 2000 All you wanted to know about spermatogonia but were afraid to ask. Journal of Andrology 21 776-798.

Sanford LM, Moore C, Voglmayr JK \& Fahmy MH 2000 Sexual maturational changes circulatory inhibin concentration in relation to FSH concentration and testicular size in Suffolk and DLS rams. Theriogenology 54 719-730.

Schneyer AL, Rzucidlo DA, Sluss PM \& Crowley WF Jr 1994 Characterization of unique binding kinetics of follistatin and activin or inhibin in serum. Endocrinology 135 667-674.
Sharpe RM, Turner KJ, McKinnell C, Groome NP, Atanassova N, Millar MR, Buchanan DL \& Cooke PS 1999 Inhibin B levels in plasma of the male rat from birth to adulthood: effect of experimental manipulation of Sertoli cell number. Journal of Andrology 20 94-101.

Small CL, Shima JE, Uzumcu M, Skinner MK \& Griswold MD 2005 Profiling gene expression during the differentiation and development of the murine embryonic gonad. Biology of Reproduction 72 492-501.

Steinberger A 1979 Inhibin production by Sertoli cells in culture. Journal of Reproduction and Fertility. Supplement 26 31-45.

Tanimoto Y, Tanimoto K, Sugiyama F, Horiguchi H, Murakami K, Yagami K \& Fukamizu A 1999 Male sterility in transgenic mice expressing activin betaA subunit gene in testis. Biochemical and Biophysical Research Communications 259 699-705.

Vassalli A, Matzuk MM, Gardner HA, Lee KF \& Jaenisch R 1994 Activin/inhibin beta B subunit gene disruption leads to defects in eyelid development and female reproduction. Genes and Development 8 414-427.

Vaughan JM, Rivier J, Corrigan AZ, McClintock R, Campen CA, Jolley D, VogImayr JK, Bardin CW, Rivier C \& Vale W 1989 Detection and purification of inhibin using antisera generated against synthetic peptide fragments. Methods in Enzymology 168 588-617.

Vejda S, Cranfield M, Peter B, Mellor SL, Groome N, Schulte-Hermann R \& Rossmanith W 2002 Expression and dimerization of the rat activin subunits betaC and betaE: evidence for the ormation of novel activin dimers. Journal of Molecular Endocrinology 28 137-148.

Vergouwen RP, Jacobs SG, Huiskamp R, Davids JA \& de Rooij DG 1991 Proliferative activity of gonocytes, Sertoli cells and interstitial cells during testicular development in mice. Journal of Reproduction and Fertility $\mathbf{9 3}$ 233-243.

Vergouwen RP, Huiskamp R, Bas RJ, Roepers-Gajadien HL, Davids JA \& de Rooij DG 1993 Postnatal development of testicular cell populations in mice. Journal of Reproduction and Fertility 99 479-485.

Vihko KK, Blauer M, Kujansuu E, Vilska S, Alback T, Tuimala R, Tuohimaa P \& Punnonen R 1998 Activin B: detection by an immunoenzymometric assay in human serum during ovarian stimulation and late pregnancy. Human Reproduction 13 841-846.

Welt CK \& Crowley WF Jr 1998 Activin: an endocrine or paracrine agent? European Journal of Endocrinology 139 469-471.

Wiater E \& Vale W 2003 Inhibin is an antagonist of bone morphogenetic protein signaling. Journal of Biological Chemistry 278 7934-7941.

de Winter JP, Themmen AP, Hoogerbrugge JW, Klaij IA, Grootegoed JA \& de Jong FH 1992 Activin receptor mRNA expression in rat testicular cell types. Molecular and Cellular Endocrinology 83 R1-R8.

de Winter JP, Vanderstichele HM, Timmerman MA, Blok LJ, Themmen AP \& de Jong FH 1993 Activin is produced by rat Sertoli cells in vitro and can act as an autocrine regulator of Sertoli cell function. Endocrinology 132 975-982.

de Winter JP, Vanderstichele HM, Verhoeven G, Timmerman MA, Wesseling JG \& de Jong FH 1994 Peritubular myoid cells from immature rat testes secrete activin-A and express activin receptor type II in vitro. Endocrinology 135 759-767.

Wreford NG, Rajendra Kumar T, Matzuk MM \& de Kretser DM 2001 Analysis of the testicular phenotype of the follicle-stimulating hormone beta-subunit knockout and the activin type II receptor knockout mice by stereological analysis. Endocrinology 142 2916-2920.

Xia Y, Sidis Y \& Schneyer A 2004 Overexpression of follistatin-like 3 in gonads causes defects in gonadal development and function in transgenic mice. Molecular Endocrinology 18 979-994.

Yoshida S, Takakura A, Ohbo K, Abe K, Wakabayashi J, Yamamoto M, Suda T \& Nabeshima Y 2004 Neurogenin3 delineates the earliest stages of spermatogenesis in the mouse testis. Developmental Biology 269 447-458.

Yu AW, Shao LE, Frigon NL Jr \& Yu J 1994 Detection of functional and dimeric activin A in human marrow microenvironment. Implications for the modulation of erythropoiesis. Annals of the New York Academy of Sciences 718 285-298 (discussion 298-289).

Received 27 March 2008

First decision 22 April 2008

Accepted 28 May 2008 